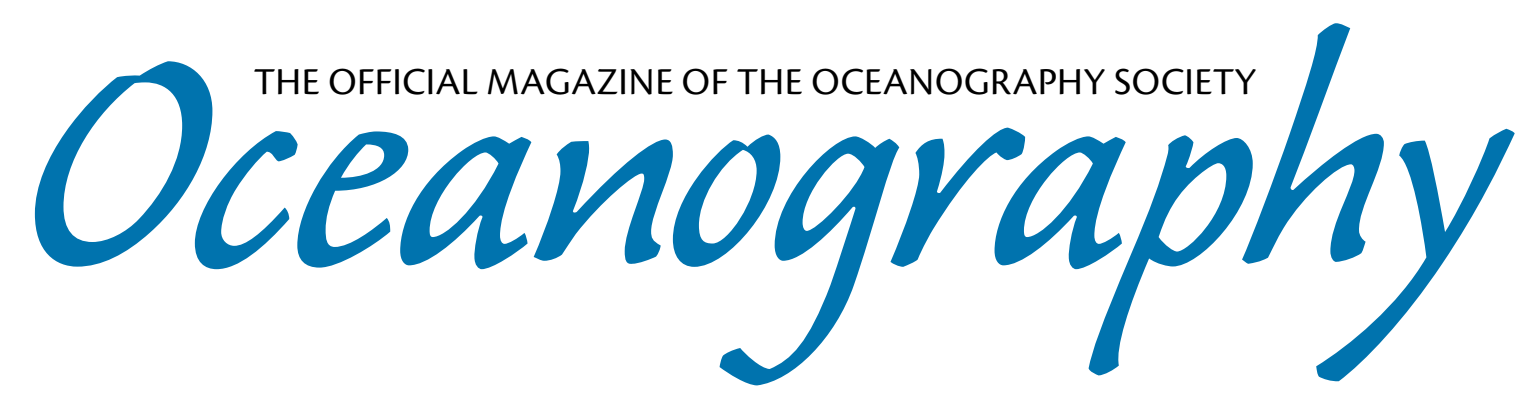

CITATION

Karl, D.M. 2014. The contemporary challenge of the sea: Science, society, and sustainability.

Oceanography 27(2):208-225, http://dx.doi.org/10.5670/oceanog.2014.57.

$\mathrm{DOI}$

http://dx.doi.org/10.5670/oceanog.2014.57

COPYRIGHT

This article has been published in Oceanography, Volume 27, Number 2, a quarterly journal of The Oceanography Society. Copyright 2014 by The Oceanography Society. All rights reserved.

USAGE

Permission is granted to copy this article for use in teaching and research. Republication, systematic reproduction, or collective redistribution of any portion of this article by photocopy machine, reposting, or other means is permitted only with the approval of The Oceanography Society. Send all correspondence to: info@tos.org or The Oceanography Society, PO Box 1931, Rockville, MD 20849-1931, USA. 


\section{Contemporary Challenge of the Sea \\ SCIENCE, SOCIETY, AND SUSTAINABILITY}

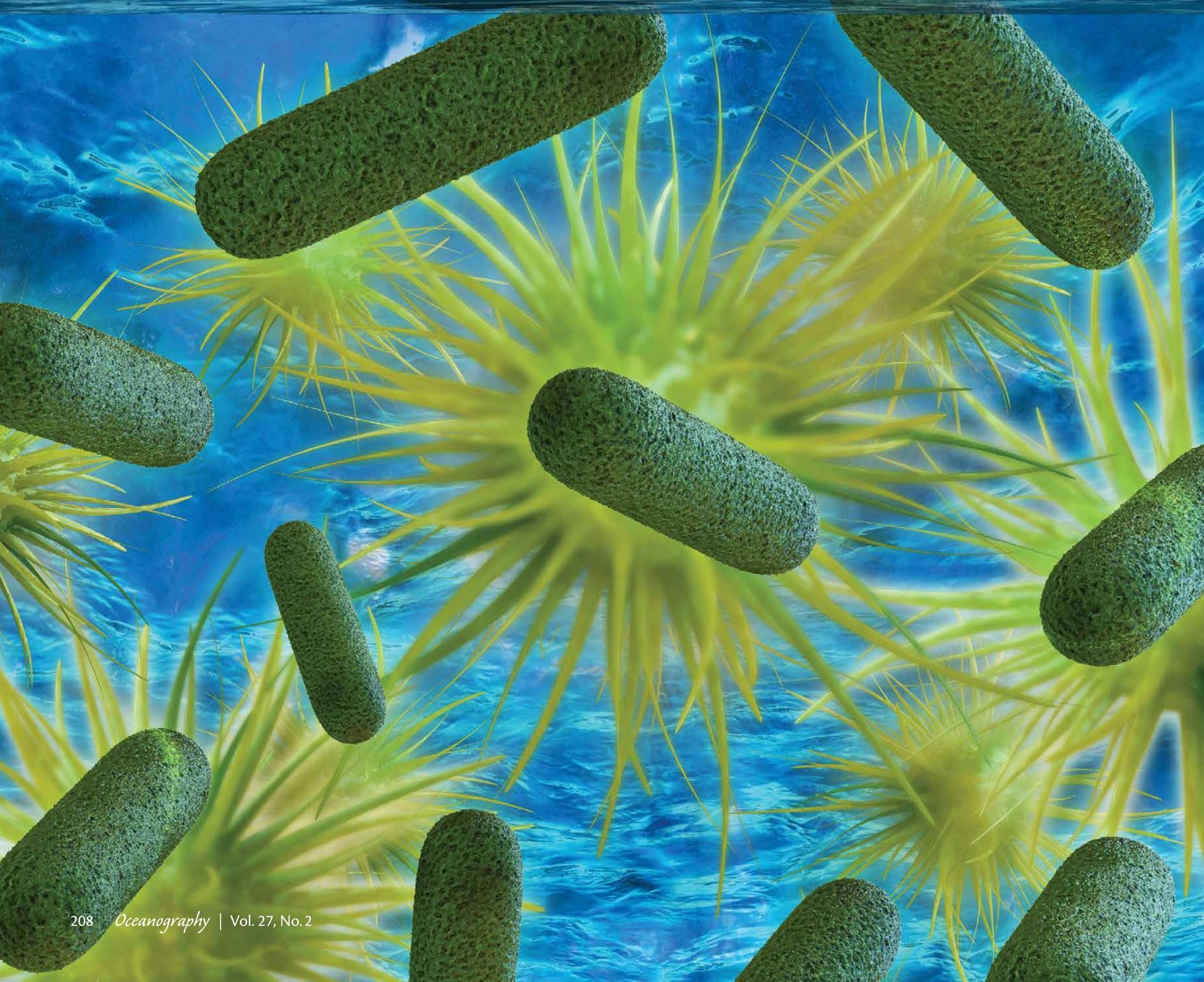




\section{The Roger Revelle Commemorative Lecture Series was created by the Ocean}

Studies Board of the National Academies in honor of Roger Revelle to highlight the important links between ocean sciences and public policy. David Karl, the fifteenth annual lecturer, spoke on March 13, 2014, at the Baird Auditorium, Smithsonian Institution, National Museum of Natural History.

\section{INTRODUCTION}

The ocean covers nearly $71 \%$ of the surface of our planet, but it is still largely unexplored despite its fundamental roles in global food production and climate regulation. The most expansive ocean regions, termed subtropical gyres (Figure 1), are the largest ecosystems on Earth, yet we know little about how they are structured, how they function, or how they may respond to stresses imposed on them by human activities. The North Pacific Subtropical Gyre (NPSG) is the largest of these gyres, and it is isolated from other ocean regions by permanent, clockwise-rotating boundary currents. The NPSG is also very old, with present boundaries having been established at least 10 million years ago (McGowan and Walker, 1985). These conditions of great age and isolation create a habitat that is nutrient starved (e.g., nitrate and phosphate) and relatively devoid of photosynthetic microbes called phytoplankton that harvest sunlight and serve as the base of the marine food chain. Although these regions have been termed "oceanic deserts" by analogy to the deserts on land, because of their vast expanse, regions such as the NPSG control global

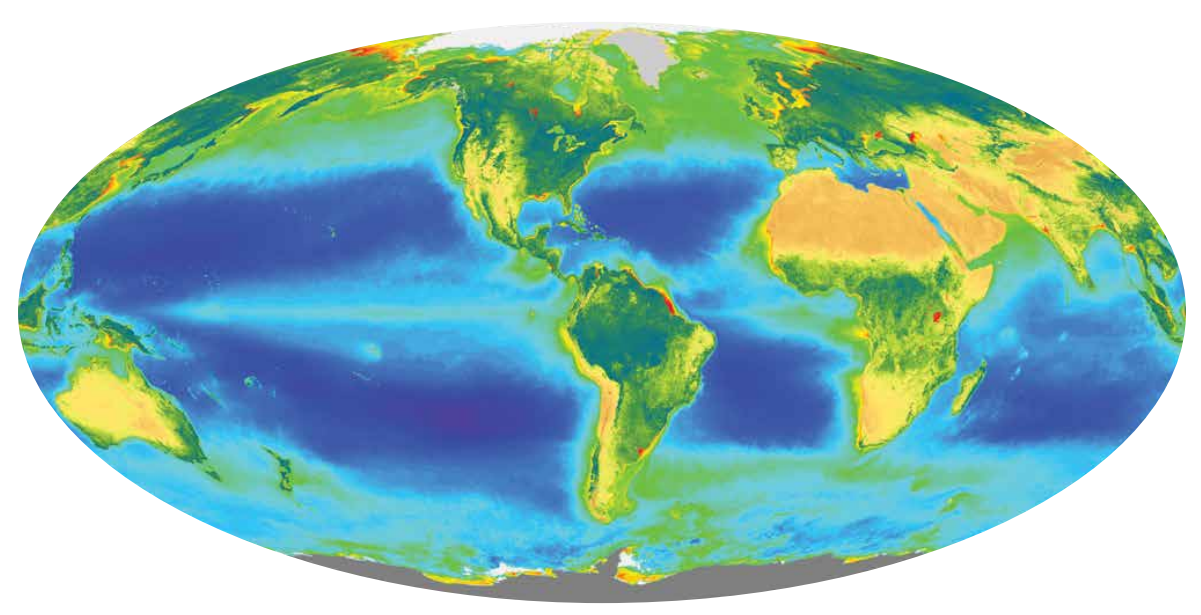

Figure 1. Global distribution of terrestrial vegetation and oceanic plant life as determined by satellite detection of chlorophyll showing a range of habitats from forests (e.g., Amazon basin in green) to deserts (e.g., oceanic subtropical gyres in dark blue). From NASA/Goddard Space Flight Center and ORBIMAGE

ocean fluxes of carbon and oxygen and therefore sustain planetary habitability. But like many open ocean regions, the NPSG ecosystem is poorly sampled and not well understood.

Roger Revelle made pioneering contributions to our understanding of the NPSG. In 1950, he organized and led the Mid-Pacific Expedition, the first of many interdisciplinary research cruises around the Hawaiian Islands. Just as in the retail sales industry, location matters, and Hawaii soon became a major center for mid-Pacific research with the establishment of the Hawaii Institute of
Geophysics in 1958, a graduate degree program in oceanography in 1962, and a School of Ocean and Earth Science and Technology in 1988, all at the University of Hawaii at Manoa (Karl, 2012). The establishment of the Hawaii Ocean Time-series (HOT) program in 1988 and the Center for Microbial Oceanography: Research and Education (C-MORE) in 2006 helped to promote the marine microbial molecular revolution that led to new discoveries regarding the diversity of life in the sea and the pathways and dynamics of matter and energy flow in the NPSG. To best understand these and 

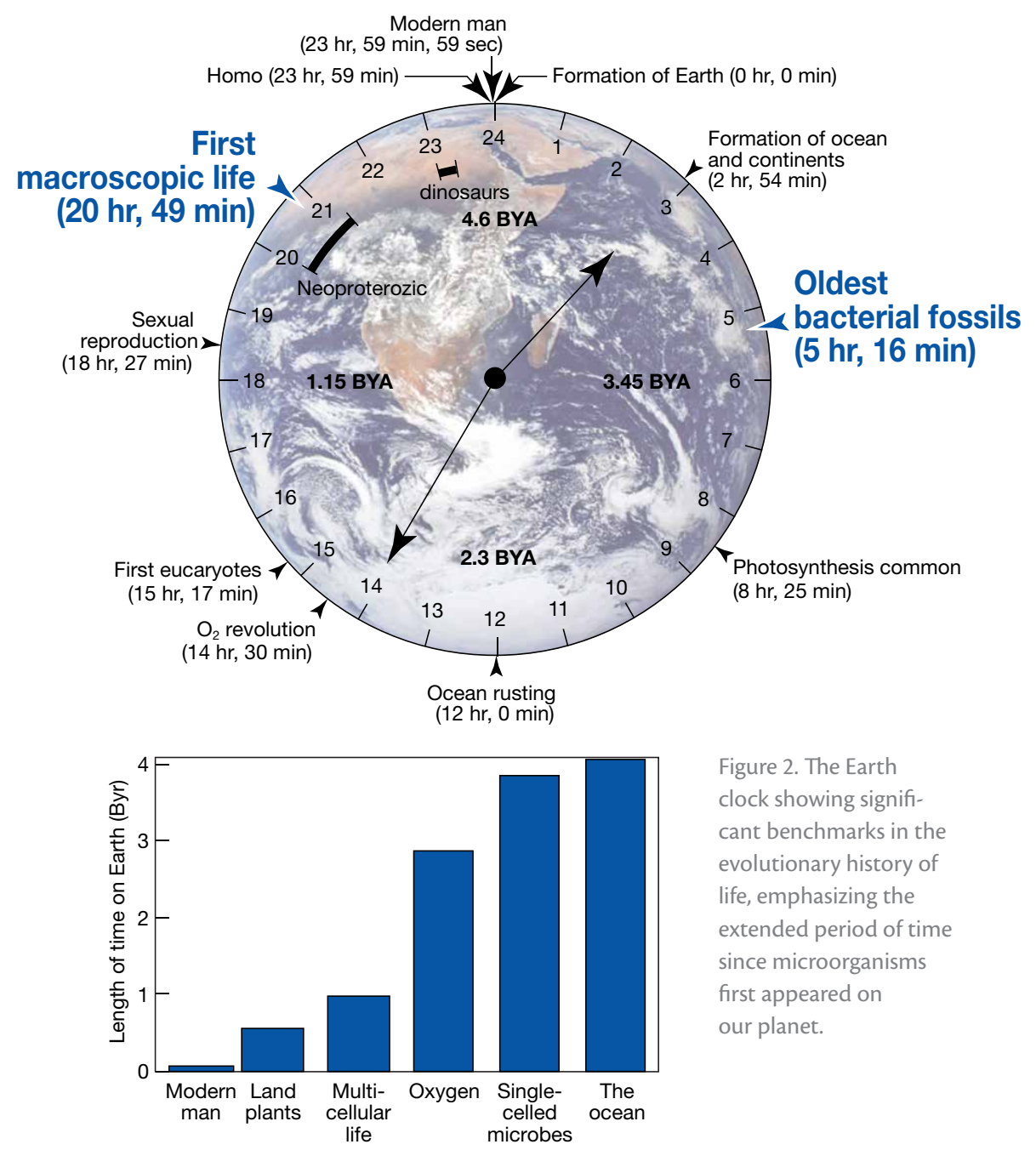
clock showing significant benchmarks in the extended period of time since microorganisms first appeared on our planet.
Figure 2. The Earth other recent achievements, a brief history lesson is in order to review the evolution of life on Earth from its origin in marine microorganisms to the ascent of man.

\section{THE ORIGIN OF LIFE ON EARTH AND THE IMPRINTS OF MICROBES AND MEN}

Planet Earth, our home, has been more than 4.6 billion years in the making. If we view Earth's history in the form of a 24-hour nautical clock, we see several important benchmarks (Figure 2). An initial cooling phase, lasting more than 500 million years, created the continents and the ocean. Then, more than 3.5 billion years ago life arose in an ancient ocean at about $0500 \mathrm{hr}$ on our Earth history clock, just before dawn. Energy in the form of radiogenic heating coupled with high-temperature seawater-rock interactions at alkaline deep-sea vents may have provided the chemical gradients necessary for electron transfer to occur (Russell et al., 2013).

\section{BOX 1. ABOUT THE TITLE-}

THE CONTEMPORARY CHALLENGE OF THE SEA:

\section{SCIENCE, SOCIETY, AND SUSTAINABILITY}

Both the title and the inspiration for this Revelle lecture derive from Arthur C. Clarke, brilliant author and futurist. In his forward-looking book, The Challenge of the Sea (1960; Holt, Rinehart, and Winston), Clarke told the story of our new underwater frontier and speculated about the tremendous impact it will have on our lives in the future. At the influential age of 10 years old, I was captivated by the great potential for future scientific discovery and motivated by Clarke's challenge of the sea. I knew right then and there that I wanted to be an oceanographer and now, more than 50 years later, I am still pursuing my dream.

Like Clarke, Roger Revelle was also a visionary. His pioneering research on the role of the coupled ocean-atmosphere system on global climate, and the impact of human societies, helped to raise awareness of the state of our planet and its vulnerabilities. These inextricably linked themes of science, society, and sustainability are among the most urgent contemporary challenges of the sea.

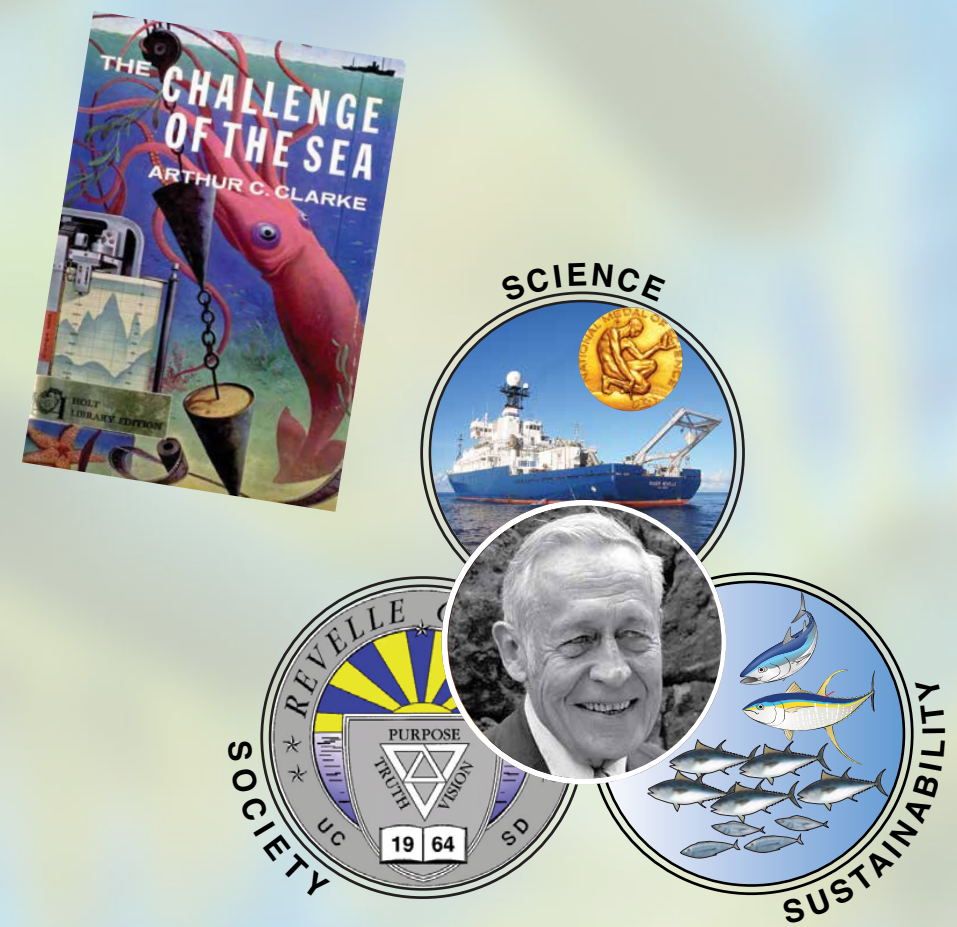


The first life forms-simple, single-celled microorganisms-evolved in an early ocean that was sulfide- and iron-rich and free of oxygen. These conditions persisted for hundreds of millions of years until the process of oxygenic photosynthesis transformed the planet, starting at about $0820 \mathrm{hr}$. This was one of the most fundamental benchmarks in our planet's history. Among other consequences, the advent of oxygen on Earth enabled the evolution of the first eukaryotes, also single-celled microorganisms, just after $1500 \mathrm{hr}$. However, it was not until much later, nearly $2100 \mathrm{hr}$, or 4 billion years after Earth's formation, that simple eukaryotes evolved into larger, more complex life forms and moved onto the land. Despite the diversity of life that evolved during our planet's history, it began and still is dominated by microorganisms and, as Arthur C. Clarke noted, "all life came from the sea and most of it is still there." Incredibly, modern humans (Homo sapiens sapiens) did not appear on Earth until about 200,000 years ago, and the period since the start of the Industrial Revolution represents a few milliseconds on the 24-hour clock of Earth history. It is amazing to think what humans have achieved during this brief time on Earth-both good deeds and evil (Figure 3; Box 2).

\section{TRACKING OF ATMOSPHERIC CARBON DIOXIDE BEGINS}

Mauna Loa, Hawaii, was selected as the site for one of the first observatories to track atmospheric concentrations of carbon dioxide $\left(\mathrm{CO}_{2}\right)$, with Roger Revelle again playing a major role in this effort and in the discovery of greenhouse gas-induced global warming. In his 1957 Tellus paper with Hans Suess, Revelle set out to measure the residence time of $\mathrm{CO}_{2}$ in the atmosphere. Based on the best information available at that time, they concluded that "the average lifetime of a $\mathrm{CO}_{2}$ molecule before dissolution into the sea is on order of 10 years" (Revelle and Suess, 1957). Revelle and Suess warned that "human beings are now carrying out a large-scale geophysical experiment of a kind that could not have happened in the past, nor be reproduced in the future." This experiment, one of humankind's doing, was an opportunity to learn more about the coupled ocean-atmosphere system, and Revelle set out to do just that during the 1957-1958 International Geophysical Year (IGY; Box 3).

Revelle, who chaired the US National Committee for IGY, and other scientists made a strong case to the committee regarding the value of making baseline atmospheric $\mathrm{CO}_{2}$ measurements against which future change could be measured. To accomplish this goal, Revelle-who was at that time also Director of Scripps Institution of Oceanography (SIO)-hired Charles David Keeling, then a postdoctoral fellow at Caltech. Initial measurements obtained in 1958 atop Mauna Loa established a baseline $\mathrm{CO}_{2}$ concentration of approximately 315 parts per million (ppm). The concentration has risen, year after year, to current levels of $\sim 400 \mathrm{ppm}$ (Figure 4 ).

David M. Karl (dkarl@hawaii.edu) is Victor and Peggy Brandstrom Pavel Chair in Ocean Science and Professor of Oceanography, University of Hawaii at Manoa, Center for Microbial Oceanography: Research and Education, Honolulu, HI, USA.

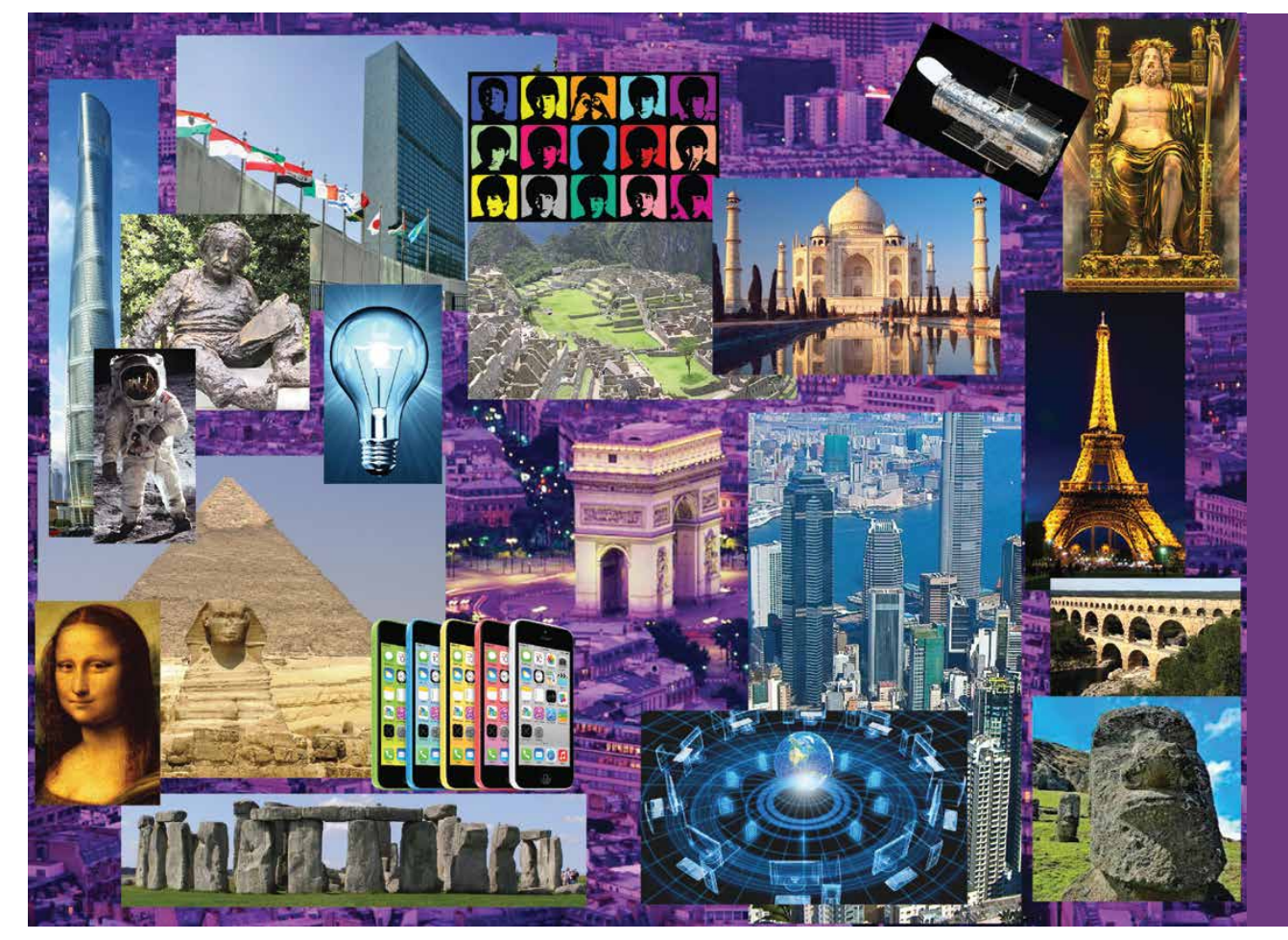

Figure 3. As stated by Marcus Antonius (Mark Antony) in his funeral oration following Julius Caesar's assassination on the Ides of March (15 March) in 44 BCE, "the evil that men do lives after them, the good is oft interred with their bones" (from: Julius Caesar, by William Shakespeare, 1599). This collage shows selected discoveries, inventions, and achievements of humankind that we can all be proud of-essentially the good interred in the bones of humankind. These contributions are offset by the "evil," including war, injustice, and the human imprint of planetary global warming via greenhouse gas emissions (see Figure 4). 
This well-calibrated, atmospheric time series is an indelible imprint of humans and an ominous warning of the future state of our planet in a businessas-usual scenario.

During a June 1963 speech at American University on world peace in the age of nuclear weapons, US President John F. Kennedy stressed that "our problems are man-made. Therefore, they can be solved by man." And, so too with global warming. In the 1999 inaugural Roger Revelle Commemorative Lecture, Peter Brewer discussed the feasibility of using technology to reduce atmospheric $\mathrm{CO}_{2}$ concentrations to fend off greenhouse gas-induced warming. Since Brewer's lecture, planetary scale geoengineering has been hotly debatedfrom efficacy to economy to ethics. In June 2011, the Intergovernmental Panel on Climate Change (IPCC) convened an Expert Meeting on Geoengineering in Lima, Peru, that focused on two proposed approaches: solar radiation management and $\mathrm{CO}_{2}$ removal. Oceanbased methods of $\mathrm{CO}_{2}$ removal include direct injection into the deep sea, chemical alteration of alkalinity through the addition of limestone, and fertilization by the addition of iron in selected regions of the surface ocean where nutrient concentrations are high. The latter method is operationally straightforward and relatively inexpensive to implement, but extremely controversial. It was initially hypothesized that iron fertilization would increase the rate of $\mathrm{CO}_{2}$ capture via photosynthesis and enhance the efficiency of the biological pump in removing carbon to the deep sea where it can be stored for decades to centuries. The surface ocean $\mathrm{CO}_{2}$ deficit would be restored by $\mathrm{CO}_{2}$ gas exchange with the atmosphere, thereby reducing the impacts of greenhouse gas warming. At least 12 major experiments with purposeful releases of iron have been conducted since 1993 (Boyd et al., 2007). While all 12 field experiments documented increases in chlorophyll (a measure of phytoplankton biomass) and rates of photosynthetic primary production, other key processes, including the coupling of photosynthesis to particle export and possible unintended ecological consequences of ocean iron fertilization, remain poorly known. Therefore, it is premature to sell carbon offsets from ocean iron fertilization until a more holistic scientific foundation of ocean ecosystem dynamics is achieved (Buesseler et al., 2008).

In 2011, the In Situ Iron Studies (ISIS) consortium of 13 institutions worldwide was established "to resolve the impact of iron fertilization on marine ecosystems, to quantify its potential for removal of atmospheric $\mathrm{CO}_{2}$, and to improve our collective understanding of the changing ocean" (http://isisconsortium.org).

Currently, none of the proposed approaches presented at the IPCC Expert Meeting on Geoengineering can be implemented on a scale that is required

The Intergovernmental Panel on Climate Change (IPCC) was established in 1988 by two United Nations organizations, the World Meteorological Organization and the United Nations Environment Programme. Its mission is to provide comprehensive scientific assessments of the world's climate. The assessment process and periodic written reports are comprehensive, objective, open, transparent, and based on relevant scientific, technical, and socio-economic information. The reports cover the physical science basis of human-induced climate change, potential impacts, and options for adaptation and mitigation. IPCC reports are policy neutral but policy relevant. A Summary for Policy Makers accompanies each report in order to facilitate a more general understanding of the technical assessment and to expedite political and societal action. To date, four reports have been completed (1990, 1995, 2001, 2007), and the fifth report is being published in three phases during 2013-2014. IPCC Assessment Report 4 shared the 2007 Nobel Peace Prize with Al Gore. Assessment Report 5, Working Group II (Impacts, adaptation and vulnerability) hosted two new chapters on the state of the ocean (Chapter 6, "Ocean Systems," and Chapter 30, "Open Oceans"). The headline statement from Assessment Report 5 is "Warming of the climate system is unequivocal, and since the 1950s many of the observed changes are unprecedented over decades to millennia" (http://www.climatechange2013.org).

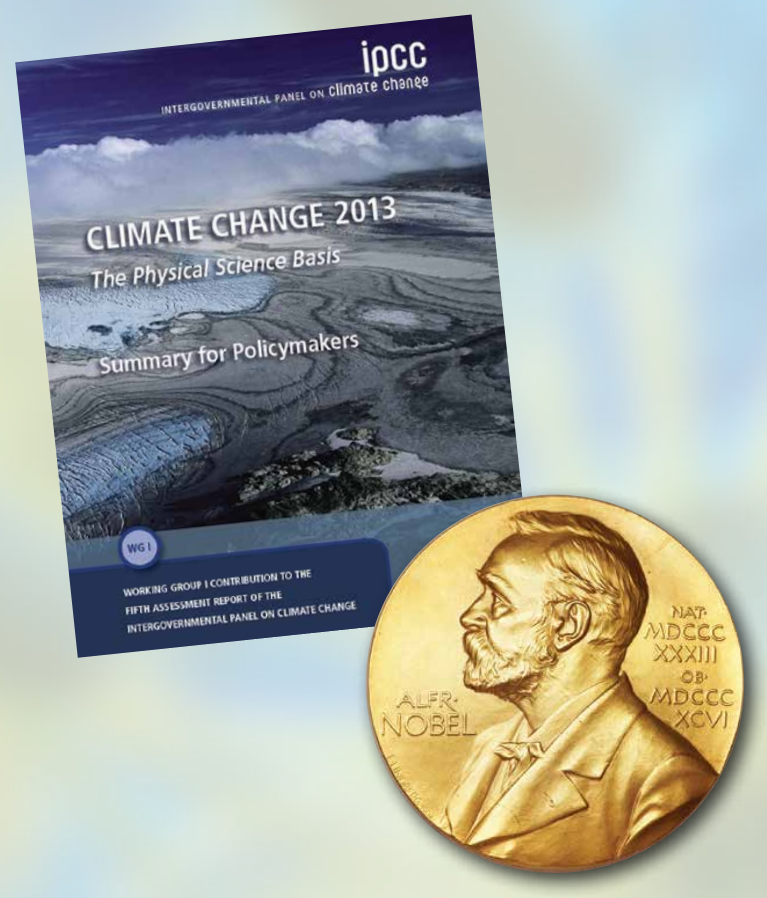


to stabilize the $\mathrm{CO}_{2}$ problem created by humankind. Effective management of greenhouse gas emissions, especially $\mathrm{CO}_{2}$, remains a major contemporary challenge for science, society, and sustainability, and possibly for our own survival.

\section{HAWAII OCEAN TIME-SERIES} AND STATION ALOHA

\section{Establishment of IGBP and JGOFS}

The ocean plays a central role in regulating global atmospheric $\mathrm{CO}_{2}$ concentration. Since the start of the Industrial Revolution, the ocean has taken up more than $25 \%$ of the $\mathrm{CO}_{2}$ that humans have added to the atmosphere (Sabine et al., 2004). The value of atmospheric time-series measurement programs initiated by Revelle and Keeling served as a key justification for the establishment of new ocean observatories to improve our understanding of the oceanic carbon cycle. The International GeosphereBiosphere Programme (IGBP): A Study

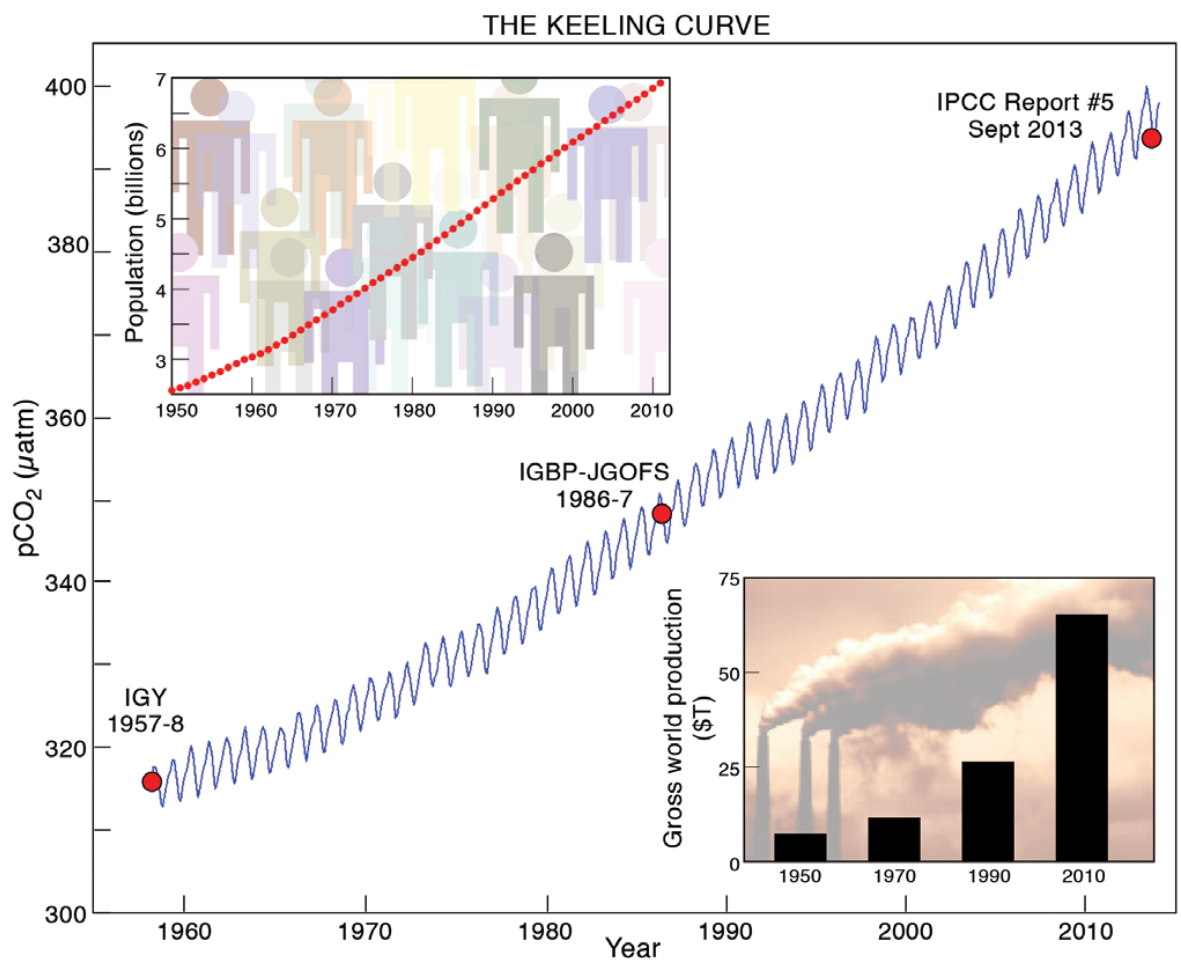

Figure 4. The Keeling curve of atmospheric carbon dioxide measured at Mauna Loa, Hawaii, from 1958 to the present, along with global human population and global world production increases since author David Karl's birth in 1950. Mauna Loa data provided by Pieter Tans, NOAA/ESRL (http://www.esrl.noaa.gov/gmd/ccgg/trends) and Ralph Keeling, Scripps Institution of Oceanography (http://scrippsco2.ucsd.edu)

\section{BOX 3. IGY (1957-1958): THE BEGINNING OF "BIG SCIENCE"}

According to an authoritative account of "big" ocean science programs written by Feenan Jennings for the National Research Council's book, Fifty Years of Ocean Discovery, the International Geophysical Year (IGY) was initially proposed as the Third Polar Year by Lloyd Berkner of the Carnegie Institution (note: The First Polar Year was in 1882-1883, and the Second Polar year was in 1932-1933). The concept was adopted by the International Council of Scientific Unions, and in 1952 was expanded to include a detailed geophysical study of the entire Earth, including its ocean. At the urging of the US National Academy of Sciences, the newly created National Science Foundation was selected as the lead agency for US science planning within the IGY, planned for 1957-1958 with logistical support from the US Navy, especially for "Operation Deep-Freeze" in Antarctica. IGY was unquestionably "big science"it involved 30,000 scientists and technicians from 66 countries collectively investigating planet Earth. The stated IGY mission was "to observe geophysical phenomena and to secure data from all parts of the world; to conduct this effort on a coordinated basis by fields, and in space and time, so that results could be collated in a meaningful manner." The atmospheric $\mathrm{CO}_{2}$ time-series measurement program on Mauna Loa, Hawaii, initiated by Charles David Keeling and Roger Revelle during IGY is still in existence today after more than five decades of data collection and analysis.

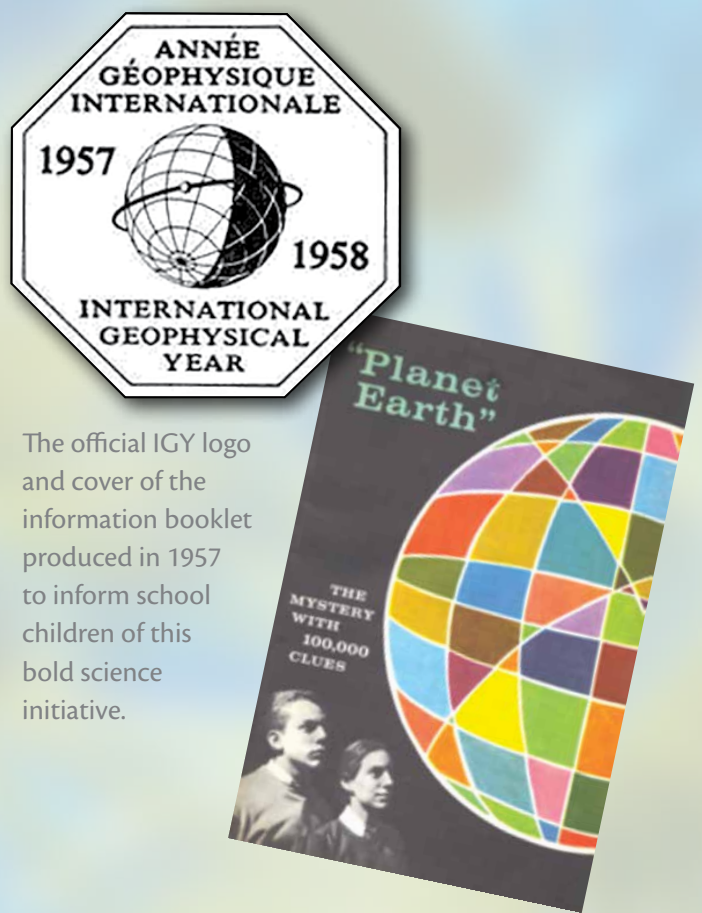

Oceanography | June 2014 
of Global Change was established in 1986, and a year later, the Joint Global Ocean Flux Study (JGOFS) was created as an essential core component of IGBP. These efforts have led to an improved understanding of the ocean, especially the biological carbon pump (Figure 5).

The origins of JGOFS date back to the establishment of the ad hoc group on ocean flux experiments (John Steele, Jim Baker, Wally Broecker, Jim McCarthy, and Carl Wunsch) under the auspices of the US National Academy of Sciences (NAS), Board on Ocean Science and Policy. At that time, Roger Revelle was a member of the Board. This committee organized a series of workshops and science planning events during the period 1983-1984 and also helped to justify and enhance financial support for global change research. The key event that gave rise to JGOFS was a five-day workshop organized to assess the state of knowledge and to plan a decade-long study to obtain a comprehensive understanding of the physical, chemical, and biological processes controlling biogeochemical cycling in the ocean and their interaction with the atmosphere. The workshop took place in September 1984 at the NAS Study Center in Woods Hole, MA; Ken Bruland served as the meeting Chair. The Global Ocean Flux Study (GOFS) report, published in late 1984, laid the groundwork for the establishment of the international JGOFS

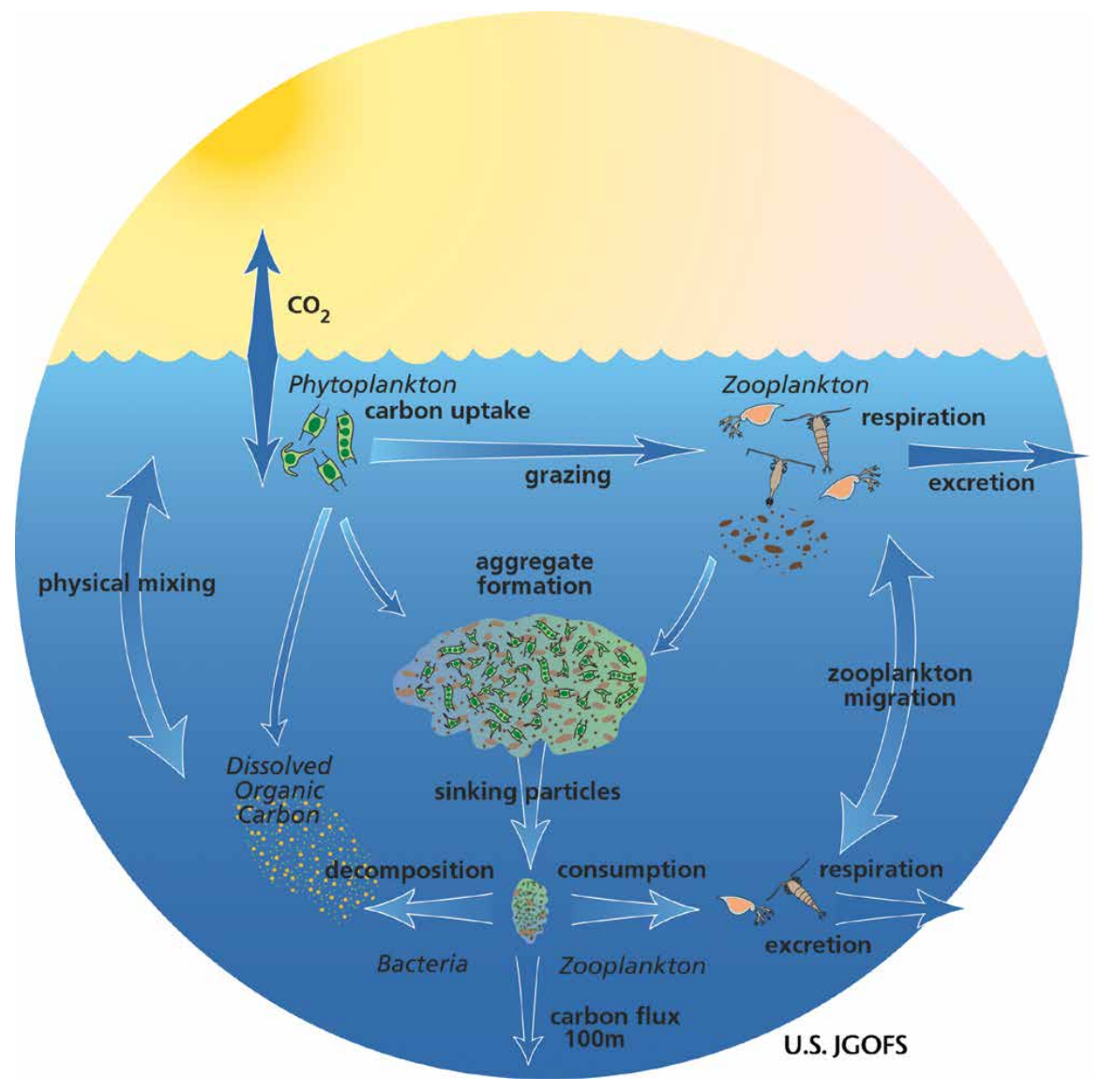

Figure 5. Schematic version of the biological carbon pump that formed the scientific basis for the Joint Global Ocean Flux Study (JGOFS), Hawaii Ocean Time-series (HOT), and Center for Microbial Oceanography: Research and Education (C-MORE) programs. Reproduced with permission from K.M. Buesseler, M. Bowles, and K. Joyce. 2001. A new wave of ocean science. US JGOFS brochure program at a Scientific Committee for Ocean Research (SCOR)-sponsored meeting at the International Council for Science (ICSU) house in Paris in February 1987 (Note: Roger Revelle was the inaugural chairman of SCOR upon its creation in 1957). In describing the situation at that time, especially the uncertainties in the rates of key carbon cycle variables and the lack of quantitative understanding of ocean dynamics, Peter Brewer (2003) concluded, "It was an interesting mess." But the science moved forward with great alacrity in large part because of visionary leaders who helped to frame the challenges and opportunities into a viable, interdisciplinary research program.

The stated goals of JGOFS were:

- To determine and understand on a global scale the processes controlling the time varying fluxes of carbon and associated biogenic elements in the ocean, and to evaluate the related exchanges with the atmosphere, seafloor, and continental boundaries

- To develop a capability to predict on a global scale the response of the oceanic biogeochemical processes to anthropogenic perturbations, in particular those related to climate change It was forcefully and successfully argued that this knowledge was urgently required because of humankind's rapid and significant influence on the global carbon cycle. JGOFS got off to a great start with the establishment of two open ocean observatories, one in the North Atlantic near Bermuda and the other in the North Pacific near Hawaii (Figure 6). The Hawaii Ocean Time-series (HOT) program benefited from previous studies in the NPSG, including extensive research conducted by scientists from Scripps, especially aperiodic investigations of the climax marine community 
located at approximately $28^{\circ} \mathrm{N}, 155^{\circ} \mathrm{W}$ from 1968-1985 (known as the CLIMAX effort), and from the University of Hawaii, especially the approximately monthly occupation of Station Gollum from January 1969-June 1970 (Figure 6). Despite the knowledge gained on previous expeditions in both ocean regions, no one could have anticipated the sheer number and magnitude of scientific discoveries the next few decades would bring.

\section{A Sea of Discovery}

Undeniable facts of oceanic ecosystems are that they are complex, time variable, and nonsteady state, they have nonlinear features, and they need to be studied as such. As data accumulate in a long-term ecological study, new phenomena become apparent and new understanding is achieved. In addition to temporal change, oceanographers and ecologists also need to understand the spatial structure of the habitat and its inhabitants. Contemporary spatial variability is probably more easily documented, studied, and understood than temporal variability; however, spatial and temporal variability in the sea are inextricably coupled (Stommel, 1963; Figure 7). The relevant scales for understanding ecosystem processes and their relationships to climate dynamics probably range from meters to hundreds of kilometers in space, and from hours to centuries in time. Integration and extrapolation of knowledge over these vast temporal and spatial scales is a major contemporary challenge for science, society, and sustainability.

The HOT program's deep ocean station, dubbed Station ALOHA (A Long-term Oligotrophic Habitat Assessment), is located at $22^{\circ} 45^{\prime} \mathrm{N}$, $158^{\circ} \mathrm{W}$, approximately $100 \mathrm{~km}$ north of Oahu, Hawaii, in deep water $(4,800 \mathrm{~m}$; Figure 6). After 25 years of intensive sampling, this NPSG site has become one of the most well-studied open ocean ecosystems, providing a global reference point for tracking the ocean's health, including the rate of atmospheric $\mathrm{CO}_{2}$ invasion and ocean acidification (Dore et al., 2009; Figure 8). Despite chronic nutrient limitation, oceanic subtropical gyres can generally support phytoplankton blooms during summer months when the water column is well stratified and most depleted of essential inorganic nutrients like nitrate and phosphate (Figure 9). These aperiodic and enigmatic phytoplankton blooms consume $\mathrm{CO}_{2}$ and recharge the upper water column with dissolved organic matter and oxygen that support postbloom heterotrophic metabolism. More importantly, blooms contribute to the seascape mosaic that is essential for maintaining genetic diversity in these expansive habitats. Station ALOHA also provides an experimental framework for studying seasonal and interannual dynamics of carbon and associated biogenic elements, for hypothesis testing experimentation, and for training the next generation of oceanographers.

At the start of the JGOFS program

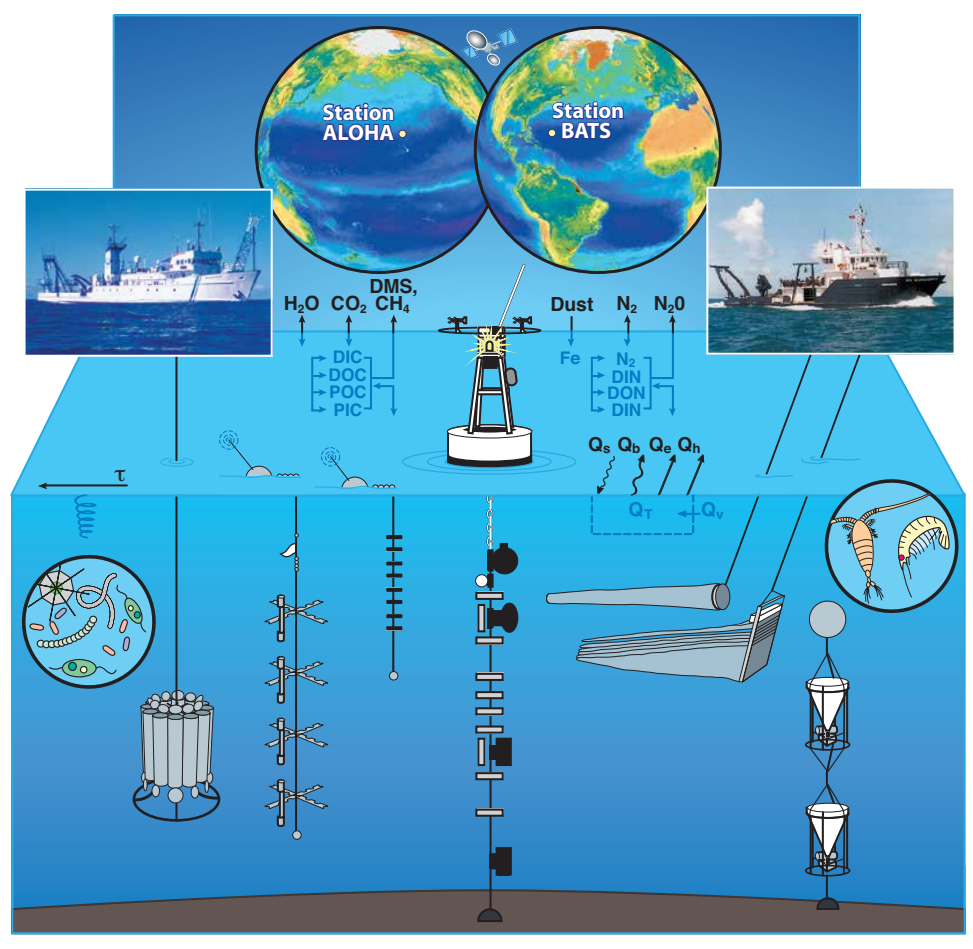

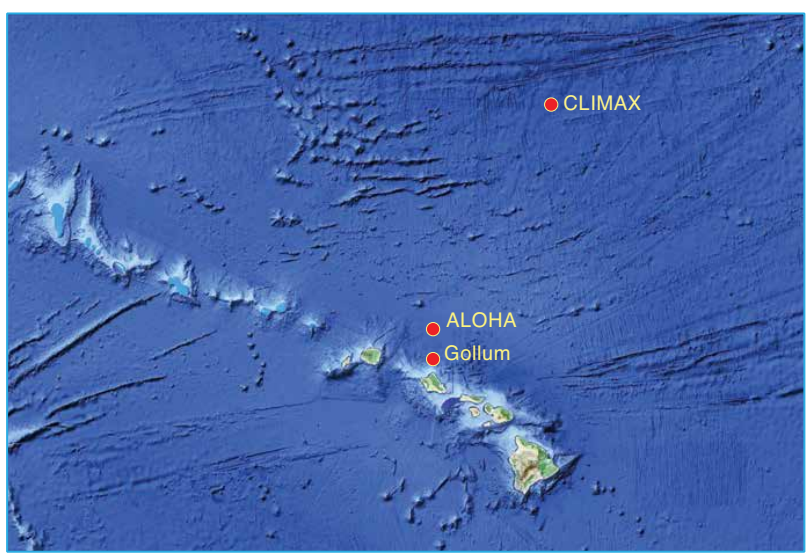

Figure 6. (left) Schematic representation showing the locations of the HOT and Bermuda Atlantic Time-series Study (BATS) locations and the sampling tools used in these time-series observation programs. (right) Location map for Station ALOHA and two previously studied time-series sites, Gollum (1969-1970) and CLIMAX (1968-1985). 
in 1987, we thought we had a fairly comprehensive understanding of the marine carbon cycle. The Redfield Ratio used to model elemental stoichiometry in the sea was well established (Redfield et al., 1963), a basic understanding of the dichotomy between new versus regenerated organic matter production was known (Dugdale and Goering, 1967), and the microbial loop food web paradigm was well established and field verified (Pomeroy, 1974; Azam et al., 1983). These were the conceptual guidelines for JGOFS program design.

However, our understanding of plankton dynamics in the sea changed radically just prior to and throughout the JGOFS era. This has forced reassessment of some of our most basic tenets of biological oceanography and marine carbon cycle research. This new understanding was achieved, in part, through the use of novel instrumentation to detect and study ocean life, especially microorganisms. For example, just as JGOFS was getting underway in 1988, Prochlorococcus, the most abundant marine plant in the sea, was discovered (Chisholm et al., 1988). We had previously considered our inventory of marine life to be complete, but now we were faced with the need to accommodate the most abundant photosynthetic organism into our ever-changing ocean carbon cycle paradigm.

One of the major goals of time-series research is to link oceanic ecosystem changes to climate variability. Just as the CLIMAX study was winding down, and prior to the start of HOT, a significant paper was published that reported a major change in plankton community structure in the NPSG. Venrick et al. (1987) observed that the average euphotic zone (0-200 m) chlorophyll concentration during summer (May-October) had nearly doubled from 1968 to 1985 . The sampling frequency was insufficient to determine whether the increase had been continuous over time or whether there had been a "stepfunction" increase between 1973 and 1980. An abrupt shift in climate, referred to as the Pacific Decadal Oscillation (PDO) was found to be coincident with the chlorophyll increase, and Venrick et al. (1987) hypothesized that this North Pacific regime shift may have caused an enhanced nutrient flux and led to a significant long-term change in the carrying capacity of the ecosystem. The first decade of HOT observations confirmed the high chlorophyll concentrations and also provided evidence for higher than expected rates of primary production. Karl et al. (2001) hypothesized that there had been a "domain shift" in the photosynthetic microbial community from a eukaryotedominated ecosystem to one dominated by Prochlorococcus. This fundamental change would have significant ecological

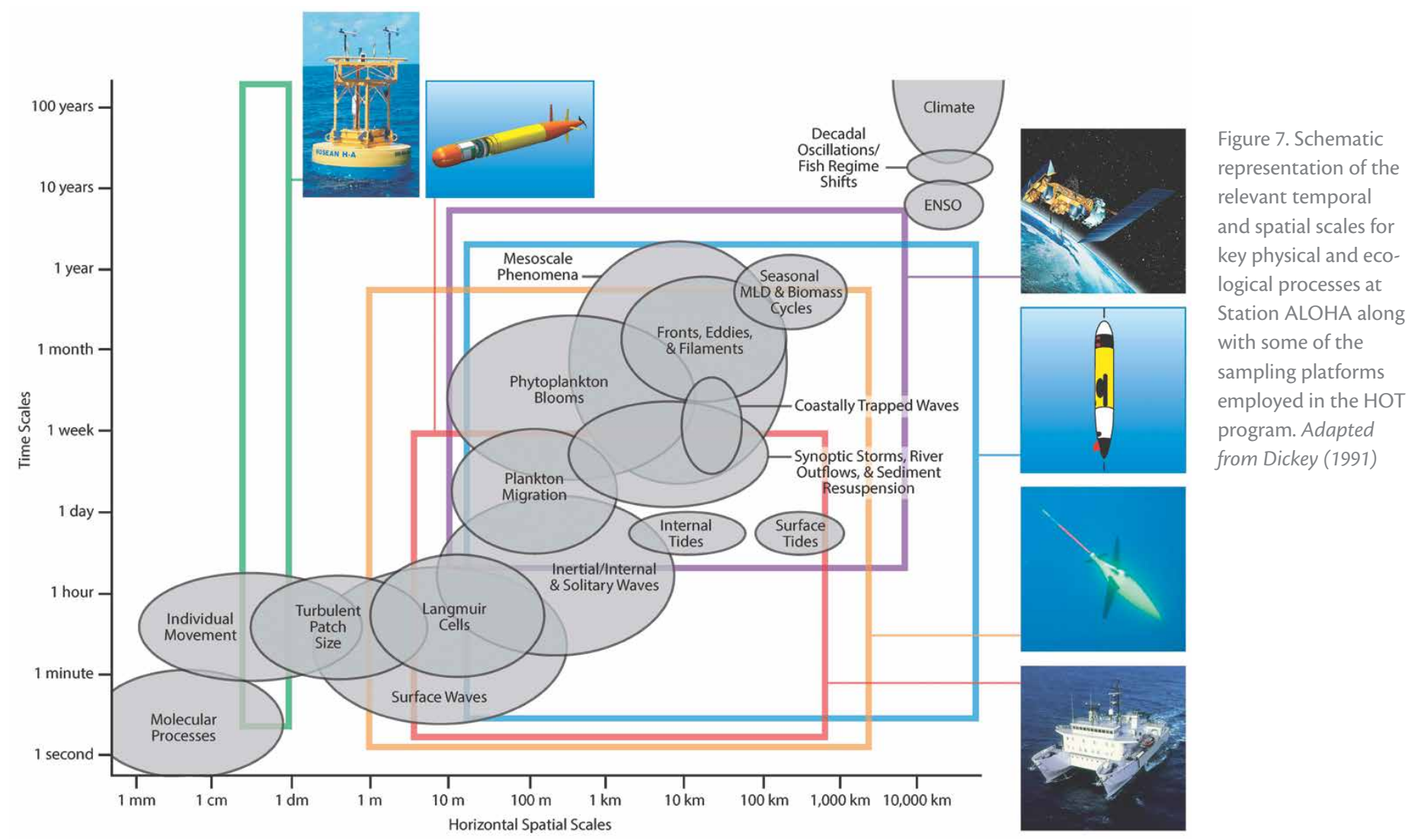


implications, including altered food web structure and changes in new, export, and fish production (Karl, 1999).

One of the unexpected and potentially significant ecological trends observed at Station ALOHA is the long-term "disappearance" of phosphorus, both dissolved and particulate, and its relationship to the coupled cycles of carbon, nitrogen, and, possibly, iron. At the start of the HOT program (October 1988), the near-surface $(0-60 \mathrm{~m})$ inventory of dissolved phosphate was approximately 6-7 mmol $\mathrm{P} \mathrm{m}^{-2}$, considered at that time to be a very low concentration. Twenty years later, the 0-60 m phosphate inventory has decreased by $80 \%$ to approximately 1-2 mmol $\mathrm{P} \mathrm{m}^{-2}$. Clearly, the balance over years to decades between $\mathrm{P}$ delivery and $\mathrm{P}$ export that maintains many marine ecosystems in a long-term steady state has been perturbed at Station ALOHA. It was hypothesized that the two-decade-long drawdown of phosphate at Station ALOHA was a manifestation of enhanced biological $\mathrm{N}_{2}$ fixation. If true, this situation could eventually lead to a 20- to 30-year cycle of $\mathrm{N}$ vs. $\mathrm{P}$ limitation of productivity, and a shift in microbial community structure and ecosystem services (Karl, 2014a). Alternatively, the recent loss of $\mathrm{P}$ from the surface waters at Station ALOHA could be a manifestation of the deposition of excess reactive $\mathrm{N}$ from the atmosphere from industrial pollution in Asia. Both natural and man-made inputs of $\mathrm{N}$ could lead to $\mathrm{P}$ depletion, but only the natural flux/pathway via biological $\mathrm{N}_{2}$ fixation is self-regulating.

The HOT program has also served as a foundation for the establishment, in 2006, of the Center for Microbial Oceanography: Research and Education (http://cmore.soest.hawaii.edu) as a complement to the ongoing Station ALOHA observation program. The improved understanding of the NPSG based on HOT program observations motivated the establishment of a center focused on developing new conceptual models and theory as well as hypothesis testing field experimentation. The new discoveries of microbial diversity and the capacity

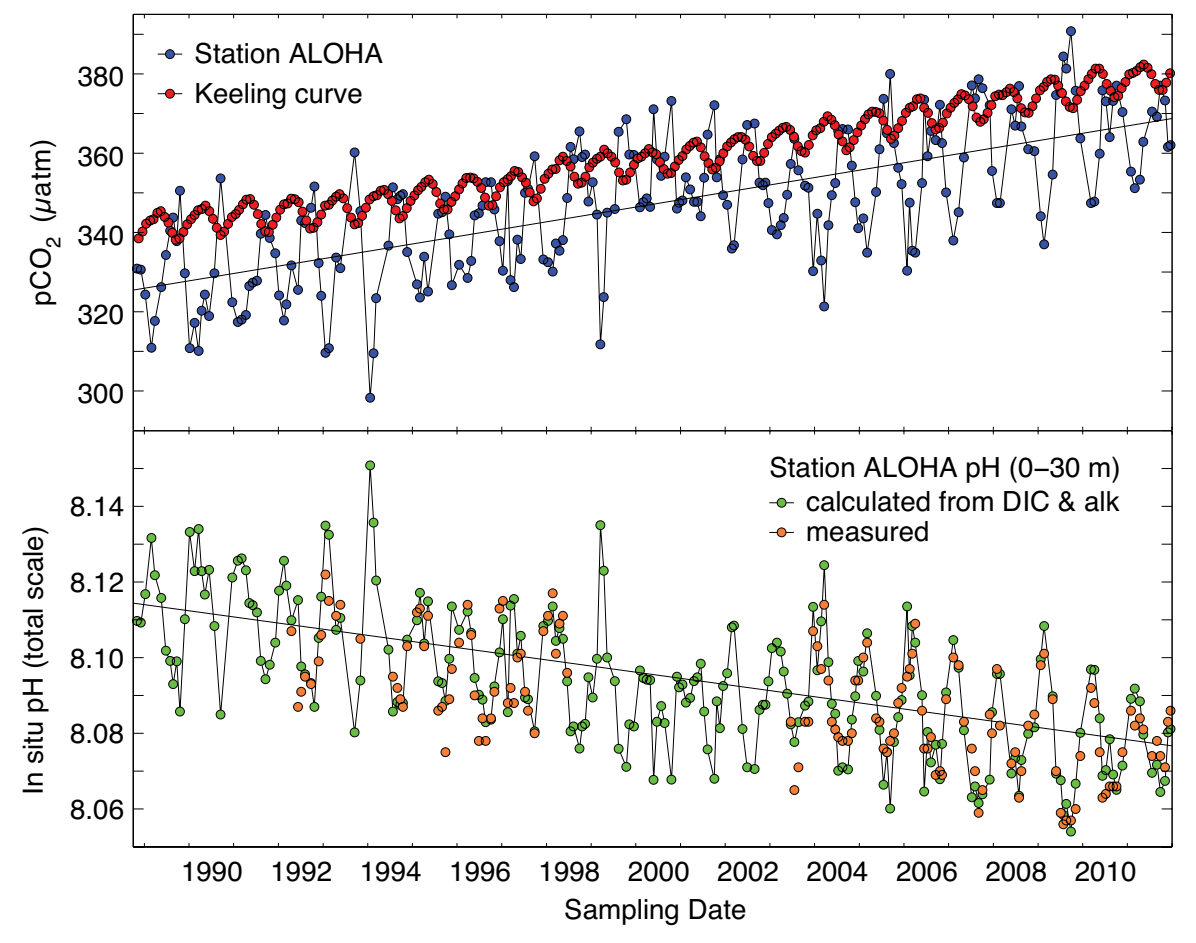

Figure 8. Station ALOHA observations from 1988-present along with the Keeling curve, showing an increase in carbon dioxide and acidification of the near surface ocean. Data from Hawaii Ocean Time-series program (http://hahana.soest.hawaii.edu). A partial version of this data set appeared in Dore et al. (2009) and received the 2009 Cozzarelli Prize from the Proceedings of the National Academy of Sciences as the year's most outstanding paper in physical sciences.

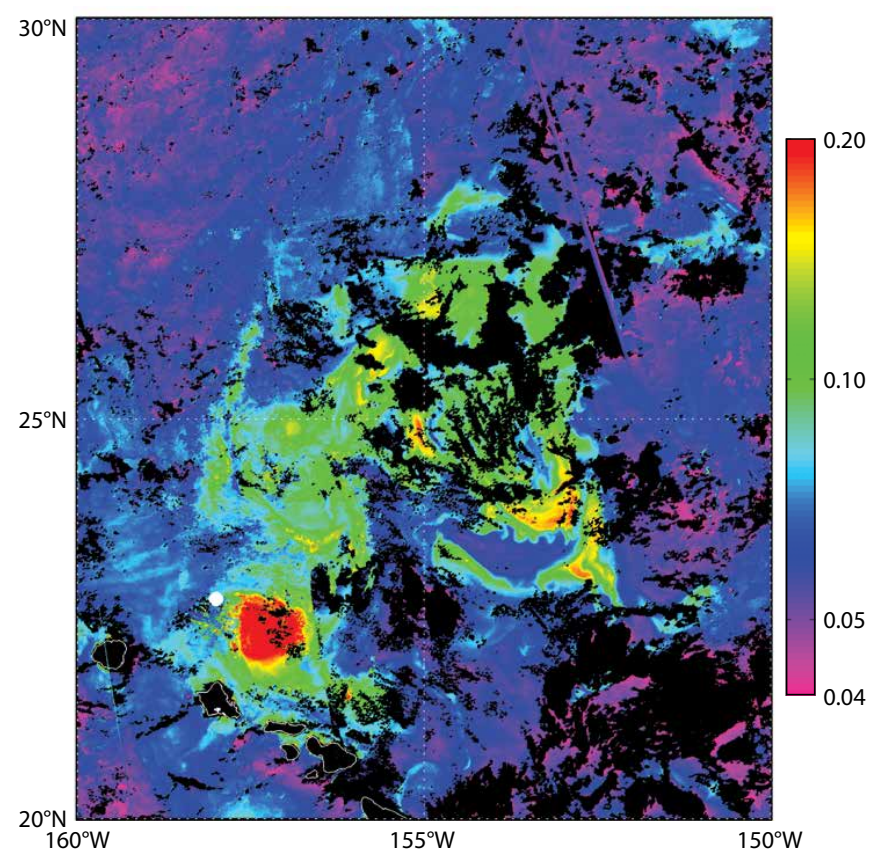

Figure 9. The ocean's desert blooms! Satellitebased chlorophyll $a$ $\left(\mathrm{mg} \mathrm{m}^{-3}\right)$ image of the region north of Hawaii showing a major phytoplankton bloom near Station ALOHA (white symbol at $22^{\circ} 45^{\prime} \mathrm{N}$, $158^{\circ} \mathrm{W}$ ) in July 2005. Image provided by J. Nahorniak (Oregon State University) using AQUA MODIS L2 ocean color data publicly available from NASA's Ocean Biology Processing Group website 
of microbes to influence the ocean's chemistry and food webs have led to new paradigms and hypotheses. As described below, these discoveries open the door on what should still be viewed as a major contemporary challenge of the sea for science, society, and sustainability.

\section{A Sea of Microbes: New Views of an Old Ocean}

Environmental change, adaptation, and evolution over Earth's history have created a diverse spectrum of plants and animals, including humans, but microorganisms have always dominated the planet and always will. For example, there are more microorganisms (bacteria, archaea, protozoa, and viruses) in one liter of seawater ( $\sim 10$ billion) than there are people on Earth ( 7 billion). Contemporary marine microbial assemblages are numerically abundant and functionally diverse. Among many vital roles, they contribute nearly one-half of global photosynthesis and thus help to sequester $\mathrm{CO}_{2}$, produce oxygen, and sustain planetary habitability. Recent discoveries of new microorganisms, some with novel solar energy capture and nutrient transformation pathways, are changing our views of how oceanic ecosystems are structured and how they function.

When HOT was initiated in 1988 , momentum was building toward development of a detailed understanding of marine microbial assemblages, their impacts on biogeochemical cycles, and the sensitivities of microbially mediated processes to climate change. Because most naturally occurring microorganisms were not in laboratory cultures, detailed taxonomic identities and metabolic characteristics were lacking and interactions among marine microorganisms were largely unexplored. Incredibly, the three major groups of microorganisms that are most abundant at Station ALOHA (Prochlorococcus, the SAR11 clade of alphaproteobacteria, and

Table 1. The Second Golden Age of Marine Microbiology (1988-present)

\begin{tabular}{|c|c|c|}
\hline Year & Discovery & Discoverer \\
\hline 1988 & $\begin{array}{l}\text { Prochlorococcus - the most abundant } \\
\text { photosynthetic microbe in the sea }\end{array}$ & S. Chisholm and colleagues \\
\hline 1990 & $\begin{array}{l}\text { SAR-11 clade - the most abundant microbe } \\
\text { in the sea }\end{array}$ & S. Giovannoni and colleagues \\
\hline 1992 & $\begin{array}{l}\text { Planktonic Archaea - the third domain of life } \\
\text { (along with bacteria and eukaryotes) }\end{array}$ & E. DeLong / J. Fuhrman \\
\hline 2000 & $\begin{array}{l}\text { Aerobic anoxygenic phototrophy - a novel, } \\
\text { specialized type of solar energy capture }\end{array}$ & Z. Kolber and colleagues \\
\hline 2000 & $\begin{array}{l}\text { Proteorhodopsin phototrophy - a novel, ubiquitous } \\
\text { type of solar energy capture }\end{array}$ & E. DeLong / O. Béjà \\
\hline 2001 & $\begin{array}{l}\text { Picoplanktonic } \mathrm{N}_{2} \text { fixers - a novel component } \\
\text { of the oceanic nitrogen cycle }\end{array}$ & J. Zehr and colleagues \\
\hline $\begin{array}{l}2005- \\
2013\end{array}$ & $\begin{array}{l}\text { Full genome sequences of marine microbes - } \\
\text { novel organisms with new genes, new proteins, } \\
\text { and new metabolic processes }\end{array}$ & many \\
\hline
\end{tabular}

\footnotetext{
${ }^{1}$ During the first Golden Age of Microbiology from 1857 to 1914, when Louis Pasteur was a principal microbiologist, the existence and importance of microbes was verified, the main bacterial agents of disease in humans and animals were discovered, and the field of immunology was developed.
} 
been discovered (Figure 11; Karl, 2014b), and this will likely lead to a quantitative reassessment of ecological energy

flow in the sea.

The first of these pathways involves solar energy capture by proteorhodopsin (PR)-containing microorganisms (Béjà et al., 2000). The PR molecule resides in the cell membrane and functions as a light-activated proton pump that produces adenosine triphosphate (ATP) but does not produce oxygen. ATP is the universal energy currency for all forms of life, and in the case of PR-based phototrophy, it is made partly by the conversion of sunlight into the chemical bond energy. In fact, it appears that most, if not all, PR-containing microbes are net consumers of oxygen and organic matter and they use light energy to supplement their organic carbon-based heterotrophic metabolism. Major roles for PR-phototrophy in the sea appear to be for both growth and survival, and they may vary among different PR-containing microbes. Goméz-Consarnau et al. (2007) were the first to report that light has a positive influence on the cell yield of a PR-containing marine bacterium when compared to cells grown in darkness. Additionally, PR-phototrophy appears to be a common mechanism for survival under environmental stress. For example, PR-phototrophy was shown to increase the long-term survival in carbon-limited cultures of marine bacteria (Steindler et al., 2011). Despite these critical roles in nature, rates of solar energy capture by this novel pathway in nature are unknown.

The second unexpected discovery was the widespread occurrence of aerobic anoxygenic phototrophs (AAP) in the tropical Pacific Ocean (Kolber et al., 2000). Like PR-based phototrophy, AAPs use both solar energy and dissolved organic matter, and they consume oxygen to support their metabolic needs. The genes coding for AAP pigment synthesis appear to be broadly distributed in marine bacteria, but as with PR-based phototrophy, their
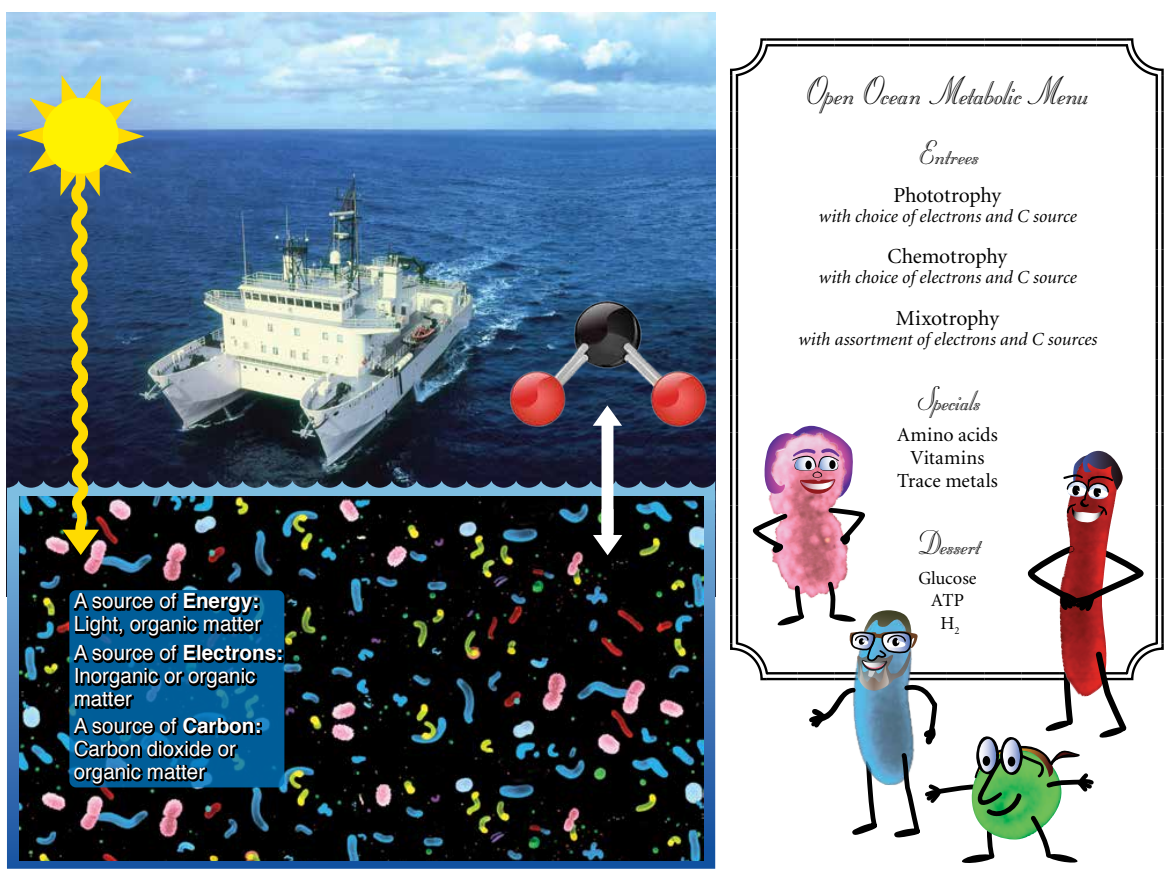

Figure 10. A sea of microbes and the diverse metabolic menu that supports them. Caricatures of the principal investigators of the C-MORE program are shown at right. Clockwise from upper left: Penny Chisholm, Ed DeLong, Jon Zehr, and Dave Karl.

\section{Solar Energy}

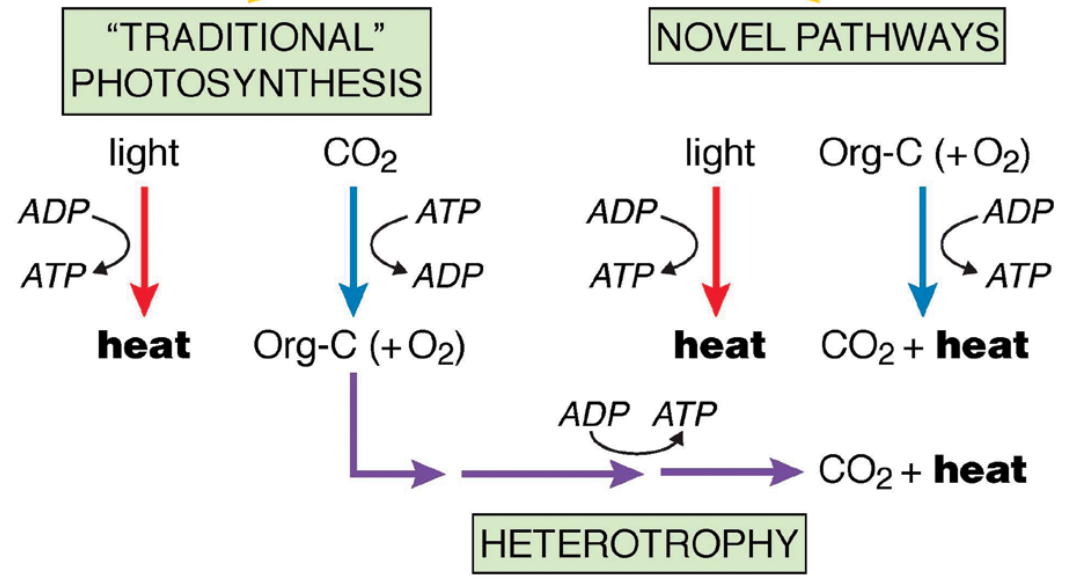

Figure 11. Schematic view of the flow of energy (red arrows), carbon (blue arrows), or energy plus carbon (purple arrows) through a hypothetical marine system. Solar energy capture processes of OP (oxygenic phototrophy) and novel pathways, including both AAP (aerobic anoxygenic phototrophy) and PR (proteorhodopsin-based phototrophy). These phototrophic pathways convert solar energy into chemical bond energy as adenosine triphosphate (ATP) plus heat, and in the case of OP, a portion of the energy gain is used to reduce carbon dioxide $\left(\mathrm{CO}_{2}\right)$ to organic matter (Org-C). The light-independent heterotrophic (HETERO) flow of carbon and energy ultimately dissipates the potential energy in Org-C to heat. From Karl (2014b) 
quantitative contribution to the ocean energy budget is unknown.

In the first ever study of gene expression in the sea using state-of-the-art metatranscriptomic analysis, Frias-Lopez et al. (2008) discovered that all three major forms of phototrophic metabolism (e.g., OP, PR, and APP) were among the most highly expressed of all gene clusters at Station ALOHA. This indicates that all three pathways may be significant for solar energy capture and transformation in the open sea.

In addition to these new pathways of solar energy capture, we have also discovered novel pathways for the transformation of carbon, nitrogen, and phosphorus - the primary building blocks of life. Some of these newly discovered metabolic processes result in the formation of nitrous oxide and methane, two gases that along with $\mathrm{CO}_{2}$ may contribute to greenhouse warming. It is imperative that we understand the environmental controls on these metabolic pathways to assess their roles in a changing ocean. In addition to the discoveries of novel microorganisms and unexpected metabolic pathways and nutrient transformations, there are also new findings regarding interactions between and among microorganisms and multicellular life forms in the sea.
Just as we are beginning to learn about the microbes that live beneficially with all of us-the human microbiomeevery marine plant and animal is likely to have a unique community of symbiotic microorganisms that it cannot live without. These are just a few examples of the vital importance of our magnificent marine microbes!

\section{RELEVANCE AND IMPORTANCE} TO MODERN SOCIETY AND GLOBAL SUSTAINABILITY In The Challenge of the Sea, Arthur C. Clarke predicted a future where the ocean would become an increasingly important source of food, energy, and natural resources as human demands outpaced and exhausted the land-based supplies. Roger Revelle also opined on these matters. In a commentary on The Harvest of the Sea and the World Food Problem, he advised that: "In thinking about the future of ocean harvest, we must consider the potentialities of both ocean farming and management of the open ocean range, the pastures of the sea." Indeed, after leaving his post as Director of the Scripps Institution of Oceanography in 1964, Revelle was appointed the Richard Saltonstall Professor of Population Policy and inaugural Director of the

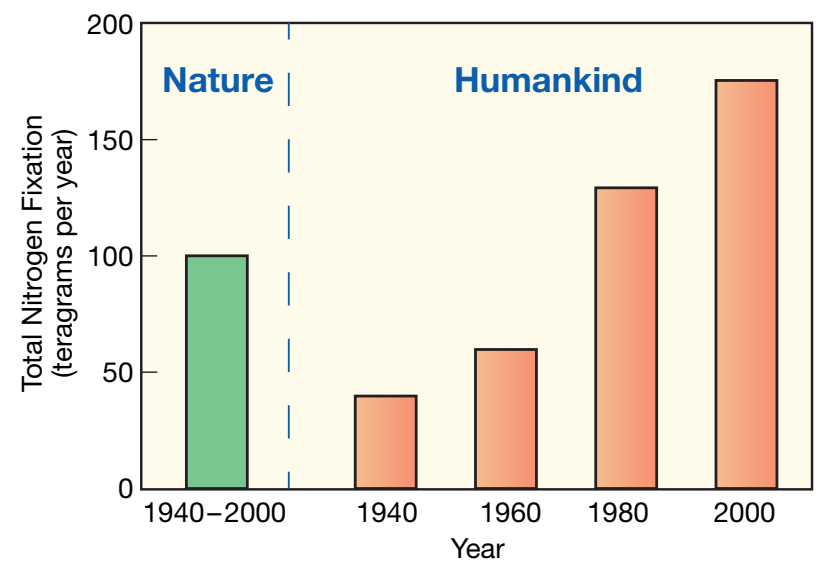

Figure 12. Global nitrogen $\left(\mathrm{N}_{2}\right)$ fixation rates by natural microbial communities (Nature) and by artificial means (Humankind; HaberBosch process) showing a rapid growth in man-made fixed $\mathrm{N}$ production over the past 60 years. 
coastal and open ocean ecosystems. Human activities, especially increased nutrient loads to rivers and estuaries, set in motion a cascade of events leading to large blooms of phytoplankton, high rates of bacterial respiration, and the death of marine organisms that require oxygen to survive (resulting in the so-called dead zones; Rabalais et al., 2014). Recent studies also show that nitrate concentrations in the surface waters of the North Pacific Ocean located downwind of fast growing economies in Northeast Asia have increased significantly since 1970 (Duce et al., 2008; Kim et al., 2011). This enhanced $\mathrm{N}$ deposition leads to a decoupling of the oceanic $\mathrm{N}$ and $\mathrm{P}$ cycles, with subsequent changes in the diversity and function of microbial assemblages and other fundamental ecosystem processes. Global surveys indicate that the impact of this man-made, reactive $\mathrm{N}$ pollution may have already reached the remote central regions of the North Pacific Ocean.

\section{Depletion of Terrestrial}

Phosphates

A major contemporary challenge for science, society, and sustainability is the future scarcity of phosphate, which is an absolute requirement for life. In a 1938 address to the US Congress, President Franklin D. Roosevelt stated: “The phosphorus content of our land, following generations of cultivation, has greatly diminished. It needs replenishing. I cannot overemphasize the importance of phosphorus not only to agriculture and soil conservation but also to the physical health and economic security of the people of the nation." This call to arms helped to fuel the green revolution, including the production of high-yield crops to feed an increasingly urbanized society. This revolution was supported by the availability of high-grade phosphate fertilizer. More recently, society has looked to biofuels (including marine microalgae) as a possible renewable energy source as fossil fuels become exhausted. However, the production of biofuels also requires phosphate, and fertilizer use in biofuel production competes head-on with food security.

In pre-industrialized societies, phosphate was cycled from farms to humans and other animal consumers back to farms through the application of organic wastes as a method to sustain soil fertility. However, advances in sanitation and public health have removed most organic wastes from the cycle, forcing the developing world to look elsewhere for sources of phosphate. Since the 1950s, mineral phosphate mined from non-renewable, land-based deposits has surpassed the global use of all other forms of phosphate for high-yield agriculture (Ashley et al.,
2011). To further complicate the present situation, global reserves of mineral phosphate are very uneven, with just five countries (Morocco, China, South Africa, Jordan, and the United States) controlling nearly all of the known global resource (Figure 13). At current rates of extraction, it is estimated that the natural resource may be exhausted in 50-100 years, probably before oil and natural gas reserves, leading to the collapse of modern agriculture and biofuel production, global strife, and inevitable famine and human suffering.

The impending global phosphate crisis has only recently been discussed among scientists, and is generally unknown to policymakers and society at large. In March 1999, Philip Abelson, distinguished physicist and US National Medal of Science honoree, wrote an editorial in the journal Science entitled "A potential phosphate crisis." In that commentary, Abelson called for "further

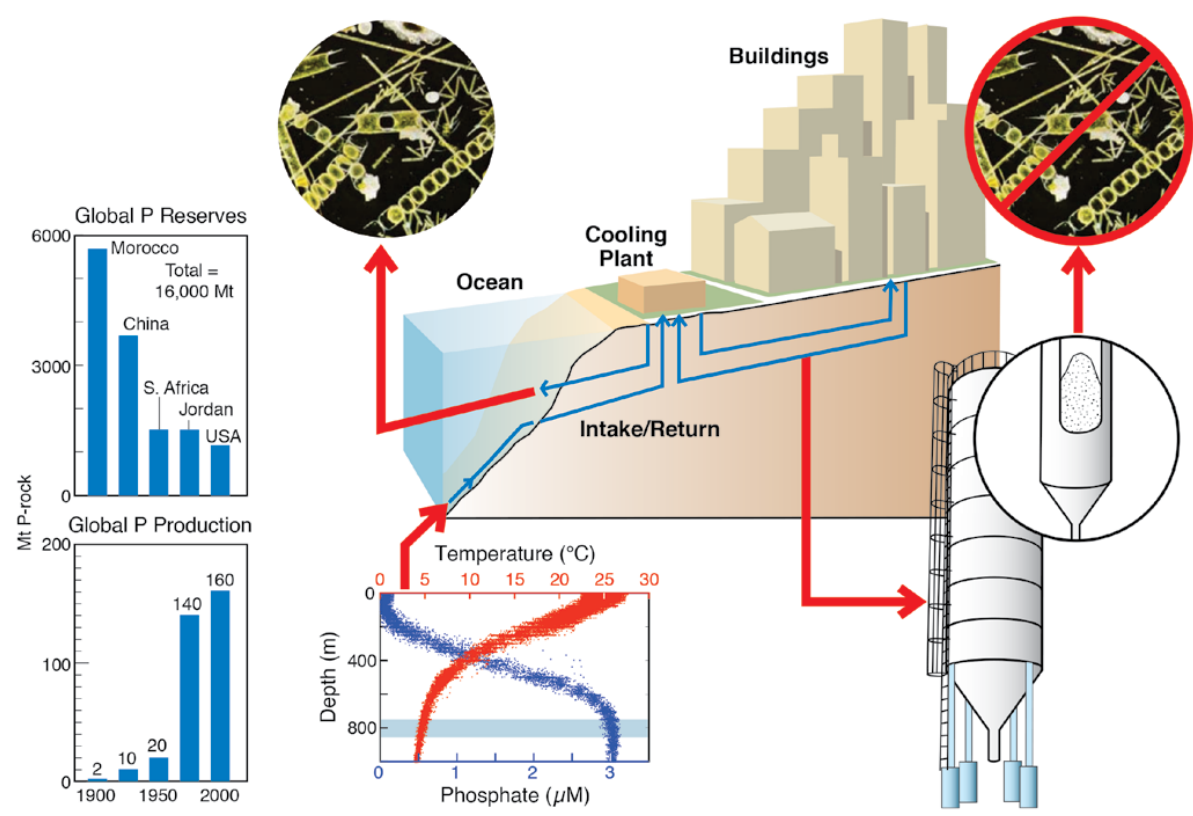

Figure 13. Schematic view of a seawater air conditioning system using cold, phosphate (P)-rich seawater as the heat exchange medium, with and without the removal of $\mathrm{P}$ prior to wastewater discharge. $P$ removal may help to control coastal nutrient pollution and phytoplankton blooms, while at the same time recovering $P$ for reuse in agriculture. Data at left show trends in global $P$ production and major $P$ reserves on land. 
research to avert problems in the long term.” More recently, a special volume of Current Opinions in Biotechnology focused on the phosphate crisis, including authoritative articles on improvements in fertilizer use in agriculture, genetic modifications to crops and livestock for more efficient use of phosphate in feeds, and phosphate capture and reuse from livestock and human wastes. However, as James Elser lamented at the close of his article entitled "Phosphorus: A limiting nutrient for humanity" (Elser, 2012), "Given the scale and scope of the needed changes in coming decades, concerted efforts in research, technology transfer, and regulatory and institutional innovation should already be well underway. I end this piece by expressing my concern that they are not." A global resolution of the phosphate crisis is a major contemporary challenge for science, society, and sustainability.

\section{The Ocean as the Solution?}

Can the ocean play a role as a new source of phosphate for humanity? While the ocean, especially at depths greater than 1,000 m, contains dissolved phosphate, it is in an extremely dilute form compared to the mineral phosphate reservoirs on land. However, the immense volume of the sea means that total $\mathrm{P}$ in the ocean is significant if only there were a method to access the deep-sea phosphate reservoir and efficiently concentrate it.

In Honolulu, Hawaii, my hometown, plans are moving forward to use deep seawater for air conditioning and for energy production using an ocean thermal energy conversion (OTEC) system (Figure 13). These novel uses of renewable resources from the sea will replace fossil fuel and, in the case of seawater air conditioning (SWAC), will also conserve freshwater that would otherwise be required for conventional air

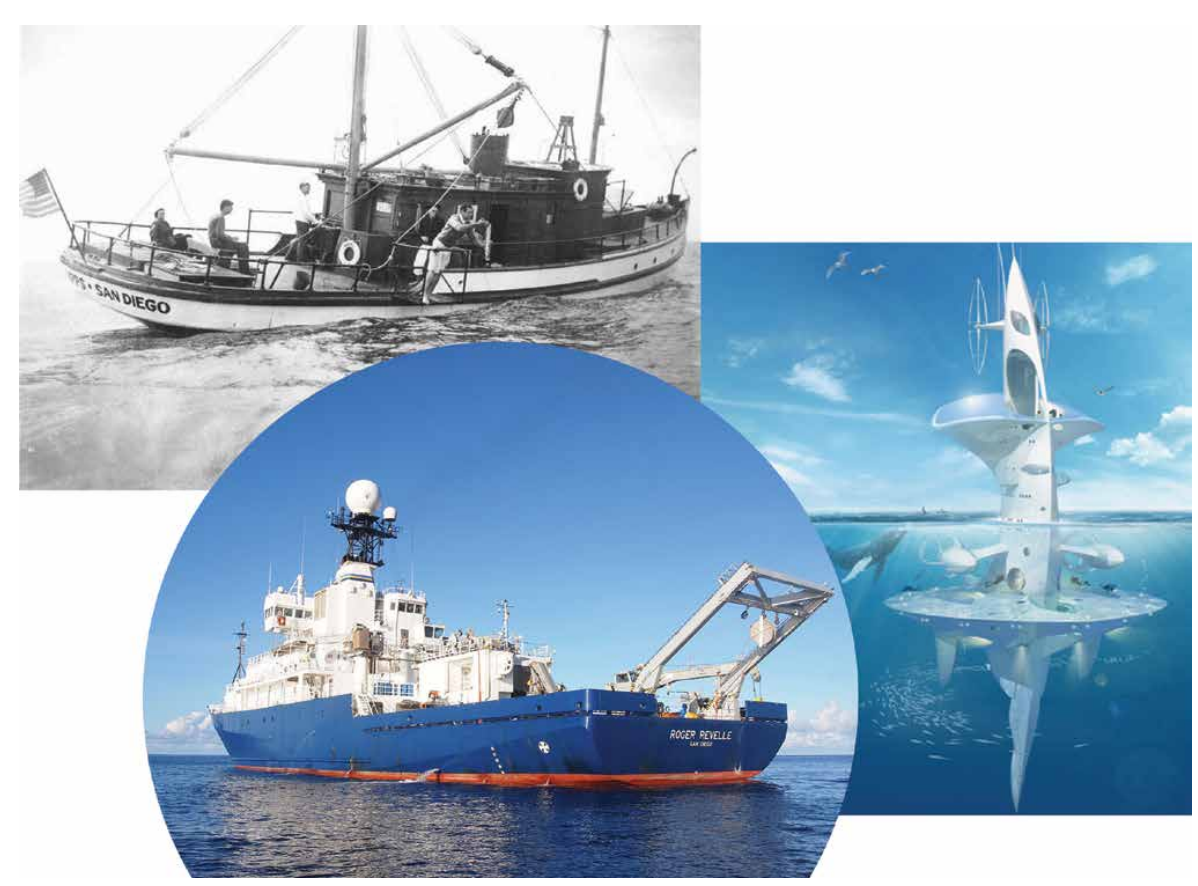

Figure 14. The changing ocean research fleet. (upper left) Roger Revelle working from the starboard deck of the E.W. Scripps off Point Loma in 1936 (from D. Day, Roger Randall Dougan Revelle Biography, Scripps Institution of Oceanography Archives; http://scilib. ucsd. edu/sio/biogr/Revelle_Biogr.pdf). (center) R/V Roger Revelle, AGOR-24, launched in 1995, and (right) SeaOrbiter, a futuristic research vessel designed for long-term observations and specialized experimentation (http: //seaorbiter.com).

conditioning cooling towers. However, a potential unintended environmental consequence of both SWAC and OTEC is nutrient pollution, especially phosphate, from discharge of the spent seawater effluent. Based on recent field experiments conducted at scales ranging from 20 liters to 60,000 liters, we have determined that the removal of phosphate prior to discharge will eliminate phytoplankton blooms that may otherwise occur. Furthermore, we have initiated laboratory-scale testing of several approaches that we believe may lead to efficient phosphate capture from the waste stream prior to coastal ocean discharge. The recovered phosphate could be sold, with the profits used to sustain basic research efforts. Development of a marine-based phosphate capture and reuse process is a major contemporary challenge for science, society, and sustainability.

\section{ACCESS TO THE SEA}

In his 1987 autobiography, How I Became an Oceanographer and Other Sea Stories, Roger Revelle chronicled his early years at SIO, especially his time at sea aboard the "research vessel" E.W. Scripps, a 65-foot former purse seiner (Revelle, 1987). After his first one-day trip to collect hydrographic data and water samples at a station 15 miles $(24 \mathrm{~km})$ off Point Loma in the San Diego Trough (Figure 14; top left), he decided "then and there that I would spend the rest of my life as an oceanographer. Being at the same time a sailor and a scientist just seemed too good to be true." Before too long, Revelle obtained the proper license and became captain of the E.W. Scripps, as well as chief scientist.

Following World War II, Harald Sverdrup, then Director of SIO, was able to obtain an ocean-going Navy tug for 
use as a more capable research vessel. The re-christened R/V Horizon was used to support the new California Cooperative Fisheries Investigation (CalCoFI) and to initiate a new phase of blue water oceanography at the institution. Revelle led the first major expedition from San Diego to the equator and on to Hawaii, to Bikini Atoll, and back to San Diego, dubbed the Mid-Pac Expedition, and two years later he organized one of the first truly multidisciplinary expeditions to the South Pacific using R/V Horizon and a second newly acquired vessel R/V Spencer F. Baird (Capricorn Expedition). These historic voyages of discovery provided important data on Earth structure, including the position of the Mohorovičić Discontinuity, heat flow and sediment characteristics, geomorphology, and other data critical to the theory of plate tectonics. Since that time, SIO has maintained a fleet of ocean class research vessels to provide access to the sea, the oceanographer's natural laboratory. In his role as Director of SIO, Revelle continued Sverdrup's vision to get scientists out of the laboratory and onto the sea by supporting additional largescale oceanographic expeditions during the 1950s. According to Walter Munk in his Tribute to Roger Revelle, the period of Revelle's leadership was the great era of the institution. "When Roger left in 1961, Scripps had a Navy bigger than that of Costa Rica" (Munk, 1997).

The ocean is currently under stress by at least three independent factors: rising temperature, acidification, and deoxygenation (Gruber, 2011). In order to track changes in the structure and function of marine ecosystems, we will need sustained observational capabilities and improved access to the sea. A recent editorial in Science by Eli Kintisch (2013) focused on the declining state of the

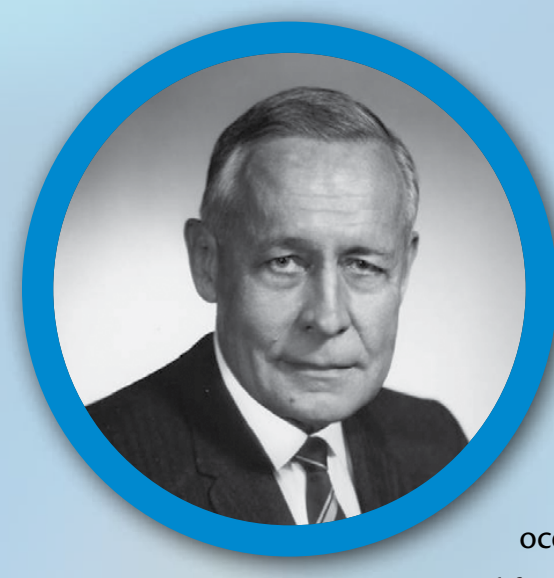

\section{Roger Revelle}

For almost half a century, Roger Revelle was a leader in the field of oceanography. Revelle trained as a geologist at Pomona College, and received his $\mathrm{PhD}$ in oceanography from the University of

California, Berkeley, in 1936. As a young naval officer, he helped persuade the Navy to create the Office of Naval Research (ONR) to support basic research in oceanography and was the first head of ONR's geophysics branch. Revelle served for 12 years as the Director of Scripps (1950-1961, 1963-1964), where he built up a fleet of research ships and initiated a decade of expeditions to the deep Pacific that challenged existing geological theory.

Revelle's early work on the carbon cycle suggested that the sea could not absorb all the carbon dioxide released from burning fossil fuels. He organized the first continual measurement of atmospheric carbon dioxide, an effort led by Charles Keeling, resulting in a longterm record that has been essential to current research on global climate change. With Hans Suess, he published the seminal paper demonstrating the connection between increasing atmospheric carbon dioxide and burning of fossil fuels. Revelle kept the issue of increasing carbon-dioxide levels before the public and spearheaded efforts to investigate the mechanisms and consequences of climate change.

Revelle left Scripps for critical posts as Science Advisor to the Department of the Interior (1961-1963) and as the first Director of the Center for Population Studies at Harvard (1964-1976). Revelle applied his knowledge of geophysics, ocean resources, and population dynamics to the world's most vexing problems: poverty, malnutrition, security, and education.

In 1957, Revelle became a member of the National Academy of Sciences to which he devoted many hours of volunteer service. He served as a member of the Ocean Studies Board, the Board on Atmospheric Sciences and Climate, and many committees. He also chaired a number of influential Academy studies on subjects ranging from the environmental effects of radiation to understanding sea level change.

Photo credit: SIO Archives, UCSD 
research fleet and predicted a grim future for essential ship-based observations and experimentation. He concluded that the US academic research fleet is shrinking, and that by 2025 there will be only six large (70-85 $\mathrm{m}$ in length), three medium (45-70 $\mathrm{m}$ in length), and four small (20-44 $\mathrm{m}$ in length) vessels remaining (Kintisch, 2013). This projected academic research fleet capacity would be less than $50 \%$ of that available in 2001 (Kintisch, 2013). Evolving technologies, including autonomous and remotely controlled assets, will likely play an increasingly important role, but research vessels will always be required for certain observations, sample collection and return, and for conducting complex experiments at sea. In addition to modern ocean class research vessels like R/V Roger Revelle (AGOR-24, launched 1995), novel human-occupied platforms such as the SeaOrbiter may provide opportunities for tomorrow's scientists to make sustained observations, study processes and interactions, and conduct long-term experiments that are not possible using conventional ships and remotely operated vehicles (Figure 14). A SeaOrbiter science planning team, led by SIO Director Emeritus Charles Kennel, is currently evaluating the scientific opportunities and defining the operational needs for SeaOrbiter, whose construction will begin in late 2014 .

There is an urgent need for enhanced access to the sea to obtain a more comprehensive understanding of marine ecosystem structure and dynamics. This is a contemporary challenge for science, society, and sustainability.

\section{FINAL REMARKS}

The contemporary challenge of the sea is enormous. There is great urgency to obtain a more comprehensive, mechanistic understanding of marine ecosystems, including the roles of microorganisms in solar energy capture and transformation and of global C, $\mathrm{N}$, and $\mathrm{P}$ cycles and their sensitivities to the impacts of a burgeoning human population, global industrialization, and climate change. I remain bullish on humankind, but believe that our future requires a greater public understanding of the sea around us, and new policies to conserve and sustain our limited natural resources. I hope that my comments might inspire a reader, young or old, to pursue a career in science or to assist with the creation of new science-based public policy. Who knows? That person might become the next Arthur C. Clarke, Ralph Cicerone, or Roger Revelle.

From my perspective, Roger Revelle's greatest legacy was the integration of science and technology with humanities and social sciences. His vision for a better world left not only a lasting impression but also unfinished business to promote public welfare. In creating a new university in San Diego, he realized, long before most others, that science, society, and sustainability were inextricably linked and inseparable in the modern world. In the future, society will become even more reliant on the sea for food and energy security, transportation, and related ecosystem services. In a 1980 lecture at Lawrence Livermore National Laboratory, Revelle lamented the "morass of uncertainties" regarding our understanding of Earth's climate system. Decisive action is needed now on issues of overpopulation, the development of alternative energy, and improving public understanding of science.

As William Nierenberg, Scripps director from 1965 to 1986, eloquently stated in an obituary following Revelle's death in 1991, “The challenges he undertook were the important ones, and they can be classified as insoluble in the sense that they are never ending. What Roger Revelle did was to improve our understanding of them and our ability to deal with them to the greatest extent possible in our times."

Finally, I leave you with a quote, indeed a credence, from Robert F. Kennedy, which is one of the most inspiring of my generation. "Some men see things as they are and say 'why?'-I dream things that never were and say 'why not."' Roger Revelle was an epic dreamer, but also a person of uncommon vision and significant achievement for science, society, and sustainability in his lifetime-Don't be afraid to dream!

\section{ACKNOWLEDGEMENTS}

I thank the National Academies' Ocean Studies Board and, especially, Director Susan Roberts and Chair Robert Duce for inviting me to deliver the $15^{\text {th }}$ Roger Revelle Commemorative Lecture, the Smithsonian Institution's Science Education Center for hosting the event in the National Museum of Natural History, National Academy of Sciences President Ralph Cicerone for his kind introduction to my lecture, and the National Oceanic and Atmospheric Administration, the National Science Foundation, the National Aeronautics and Space Administration, the Office of Naval Research, the US Geological Survey, Scripps Institution of Oceanography, and the Gordon and Betty Moore Foundation for their generous support of the Roger Revelle Commemorative Lecture Series. Finally, I thank Stacee Karras, Susan Roberts, Lisa Lum, and Nancy Hulbirt for their invaluable assistance in preparing, illustrating, and improving my Roger Revelle Commemorative Lecture. 


\section{REFERENCES}

Abelson, P.H. 1999. A potential phosphate crisis. Science 283:2,015, http://dx.doi.org/10.1126/ science.283.5410.2015.

Ashley, K., D. Cordell, and D. Mavinic. 2011. A brief history of phosphorus: From the philosopher's stone to nutrient recovery and reuse. Chemosphere 84:737-746, http://dx.doi.org/ 10.1016/j.chemosphere.2011.03.001.

Azam, F., T. Fenchel, J.G. Field, J.S. Gray, L.A. Meyer-Reil, and F. Thingstad. 1983. The ecological role of water-column microbes in the sea. Marine Ecology Progress Series 10:257-263.

Béjà, O., L. Aravind, E.V. Koonin, M.T. Suzuki, A. Hadd, L.P. Nguyen, S.B. Jovanovich, C.M. Gates, R.A. Feldman, J.L. Spudich, and others. 2000. Bacterial rhodopsin: Evidence for a new type of phototrophy in the sea. Science 289:1,902-1,906, http://dx.doi.org/ 10.1126/science.289.5486.1902.

Boyd, P.W., T. Jickells, C.S. Law, S. Blain, E.A. Boyle, K.O. Buesseler, K.H. Coale, J.J. Cullen, H.J.W. de Baar, M. Follows, and others. 2007. Mesoscale iron enrichment experiments 1993-2005: Synthesis and future directions. Science 315:612-617, http://dx.doi.org/10.1126/science.1131669.

Brewer, P.G. 2003. Foreword. Pp. I-VIII in Ocean Biogeochemistry: A Synthesis of the Joint Global Ocean Flux Study (JGOFS). M.J. Fasham, ed., Springer-Verlag.

Buesseler, K.O., S.C. Doney, D.M. Karl, P.W. Boyd, K. Caldeira, F. Chai, K.H. Coale, H.J. de Baar, P.G. Falkowski, K.S. Johnson, and others. 2008. Ocean iron fertilization-Moving forward in a sea of uncertainty. Science 319:162, http://dx.doi.org/10.1126/science.1154305.

Chisholm, S.W., R.J. Olson, E.R. Zettler,

R. Goericke, J.B. Waterbury, and

N.A. Welschmeyer. 1988. A novel free-living prochlorophyte abundant in the oceanic euphotic zone. Nature 334:340-343, http://dx.doi.org/10.1038/334340a0.

Dickey, T.D. 1991. The emergence of concurrent high-resolution physical and bio-optical measurements in the upper ocean and their applications. Reviews of Geophysics 29:383-413, http://dx.doi.org/10.1029/91RG00578.

Dore, J.E., R. Lukas, D.W. Sadler, M.J. Church, and D.M. Karl. 2009. Physical and biogeochemical modulation of ocean acidification in the central North Pacific. Proceedings of the National Academy of Sciences of the United States of America 106:12,235-12,240, http://dx.doi.org/ 10.1073/pnas.0906044106.

Duce, R.A., J. LaRoche, K. Altieri, K.R. Arrigo, A.R. Baker, D.G. Capone, S. Cornell, F. Dentener, J. Galloway, R.S. Ganeshram, and others. 2008. Impacts of atmospheric anthropogenic nitrogen on the open ocean. Science 320:893-897, http://dx.doi.org/10.1126/ science.1150369.

Dugdale, R.C., and J.J. Goering. 1967. Uptake of new and regenerated forms of nitrogen in primary productivity. Limnology and Oceanography 12:196-206, http://dx.doi.org/ 10.4319/lo.1967.12.2.0196.
Elser, J.J. 2012. Phosphorus: A limiting nutrient for humanity? Current Opinion in Biotechnology 23:833-838, http://dx.doi.org/ 10.1016/j.copbio.2012.03.001.

Fasham, M.J.R., B.M. Balino, and M.C. Bowles, eds. 2001. A new vision of ocean biogeochemistry after a decade of the Joint Global Ocean Flux Study (JGOFS). Ambio Special Report 10, Royal Swedish Academy of Sciences, Stockholm, Sweden, $31 \mathrm{pp}$.

Frias-Lopez, J., Y. Shi, G.W. Tyson, M.L. Coleman, S.C. Schuster, S.W. Chisholm, and E.F. DeLong. 2008. Microbial community gene expression in ocean surface waters. Proceedings of the National Academy of Sciences of the United States of America 105:3,805-3,810, http://dx.doi.org/10.1073/pnas.0708897105.

Gilbert, J.A., and C.L. Dupont. 2011. Microbial metagenomics: Beyond the genome. Annual Review of Marine Science 3:347-371, http://dx.doi.org/10.1146/ annurev-marine-120709-142811.

Goméz-Consarnau, L., J.M. González, M. Coll-Lladó, P. Gourdon, T. Pascher, R. Neutze, C. Pedrós-Alió, and J. Pinhassi. 2007. Light stimulates growth of proteorhodopsin-containing marine Flavobacteria. Nature 445:210-213, http://dx.doi.org/10.1038/ nature05381.

Gruber, N. 2011. Warming up, turning sour, losing breath: Ocean biogeochemistry under global change. Philosophical Transactions of the Royal Society A 369:1,980-1,996, http://dx.doi.org/ 10.1098/rsta.2011.0003.

Karl, D.M. 1999. A sea of change: Biogeochemical variability in the North Pacific subtropical gyre. Ecosystems 2:181-214, http://dx.doi.org/ $10.1007 /$ s100219900068.

Karl, D.M. 2012. Mid-Pacific oceanography: University of Hawaii and the sea. Mains'l Haul 48:88-99, http://hahana.soest.hawaii.edu/ lab/dkarl/2012Mainsl-Haul48-88-99.pdf.

Karl, D.M. 2014a. Microbially mediated transformations of phosphorus in the sea: New views of an old cycle. Annual Review of Marine Science 6:279-337, http://dx.doi.org/10.1146/ annurev-marine-010213-135046.

Karl, D.M. 2014b. Solar energy capture and transformation in the sea. Elementa, http://dx.doi.org/10.12952/journal. elementa.000021.

Karl, D.M., R.R. Bidigare, and R.M. Letelier. 2001. Long-term changes in plankton community structure and productivity in the North Pacific Subtropical Gyre: The domain shift hypothesis. Deep Sea Research Part II 48:1,449-1,470, http://dx.doi.org/10.1016/S0967-0645(00) 00149-1.

Kim, T.-W., K. Lee, R.G. Najjar, H.-D. Jeong, and H.J. Jeong. 2011. Increasing $\mathrm{N}$ abundance in the northwestern Pacific Ocean due to atmospheric nitrogen deposition. Science 334:505-509, http://dx.doi.org/10.1126/science.1206583.

Kintisch, E. 2013. A sea change for US oceanography. Science 339:1,138-1,143, http://dx.doi.org/ 10.1126/science.339.6124.1138.
Kolber, Z.S., C.L. Van Dover, R.A. Niederman, and P.G. Falkowski. 2000. Bacterial photosynthesis in surface waters of the open ocean. Nature 407:177-179, http://dx.doi.org/ 10.1038/35025044.

McGowan, J.A., and P.W. Walker. 1985. Dominance and diversity maintenance in an oceanic ecosystem. Ecological Monographs 55:103-118, http://dx.doi.org/10.2307/1942527.

Munk, W.H. 1997. Tribute to Roger Revelle and his contribution to studies of carbon dioxide and climate change. Proceedings of the National Academy of Sciences of the United States of America 94:8,275-8,279.

Pomeroy, L.R. 1974. The ocean's food web: A changing paradigm. BioScience 24:409-504, http://dx.doi.org/10.2307/1296885.

Rabalais, N.N., W.-J. Cai, J. Carstensen, D.J. Conley, B. Fry, Z. Hu, Z. Quiñones-Rivera, R. Rosenberg, C.P. Slomp, R.E. Turner, and others. 2014. Eutrophication-driven deoxygenation in the coastal ocean. Oceanography 27(1):172-183, http://dx.doi.org/ 10.5670/oceanog.2014.21.

Redfield, A.C., B.H. Ketchum, and F.A. Richards. 1963. The influence of organisms on the composition of sea water. Pp. 26-77 in The Sea, vol. 2. M.N. Hill, ed, Interscience.

Revelle, R. 1987. How I became an oceanographer and other sea stories. Annual Review of Earth and Planetary Sciences 15:1-23, http://dx.doi.org/10.1146/annurev.ea.15. 050187.000245 .

Revelle, R., and H.E. Suess. 1957. Carbon dioxide exchange between atmosphere and ocean and the question of an increase of atmospheric $\mathrm{CO}_{2}$ during the past decades. Tellus 9 , http://dx.doi.org/10.1111/j.2153-3490.1957. tb01849.x.

Russell, M.J., W. Nitschke, and E. Branscomb. 2013. The inevitable journey to being. Philosophical Transactions of the Royal Society B 368, 20120254, http://dx.doi.org/ 10.1098/rstb.2012.0254.

Sabine, C.L., R.A. Feely, N. Gruber, R.M. Key, K. Lee, J.L. Bullister, R. Wanninkhof, C.S. Wong, D.W.R. Wallace, B. Tilbrook, and others. 2004. The oceanic sink for anthropogenic $\mathrm{CO}_{2}$. Science 305:367-371, http://dx.doi.org/10.1126/ science.1097403.

Steindler, L., M.S. Schwalbach, D.P. Smith, F. Chan, and S.J. Giovannoni. 2011. Energy starved Candidatus Pelagibacter ubique substitutes light-mediated ATP production for endogenous carbon respiration. PloS ONE 6(5):e19725, http://dx.doi.org/10.1371/journal.pone. 0019725 .

Stommel, H. 1963. Varieties of oceanographic experience. Science 139:572-576, http://dx.doi.org/10.1126/science.139.3555.572.

Venrick, E.L., J.A. McGowan, D.R. Cayan, and T.L. Hayward. 1987. Climate and chlorophyll a: Long-term trends in the central North Pacific Ocean. Science 238:70-72, http://dx.doi.org/ 10.1126/science.238.4823.70. 